\title{
RECONSTRUCTION OF THE THORACIC EPAXIAL MUSCULATURE OF DIPLODOCID AND DICRAEOSAURID SAUROPODS
}

\author{
DANIELA SCHWARZ-WINGS* \\ Naturhistorisches Museum Basel, Augustinergasse 2, 4001 Basel, Switzerland
}

\begin{abstract}
Thoracic epaxial muscles of diplodocid and dicraeosaurid sauropods are reconstructed for the first time using an Extant Phylogenetic Bracket approach. In the dorsal vertebral column, three different epaxial muscle groups were present. The medialmost $\mathrm{m}$. transversospinalis and the laterally adjacent $\mathrm{m}$. longissimus dorsi were connected to the neural arches. The lateralmost $\mathrm{m}$. iliocostalis was connected to the dorsal ribs. The medial part of $\mathrm{m}$. transversospinalis of diplodocids and dicraeosaurids comprised at least two tendon systems that had a trellis-like arrangement. Osteological characters of the dorsal vertebrae in related taxa suggest a similar configuration of the thoracic epaxial muscles in all eusauropods, although there was variation in tendon arrangements and in the cross-section of each muscle. The thoracic epaxial musculature in eusauropods played an important role for trunk support; its variation in different eusauropods is directly connected with bony support structures and influenced the mobility of the trunk and locomotion. Modifications in the thoracic epaxial musculature are especially apparent in Saltasauridae, which suggests differences in their locomotor capabilities, such as increased trunk mobility or larger stride lengths.
\end{abstract}

\section{INTRODUCTION}

Thoracic epaxial musculature forms an important bracing mechanism that contributes to the accommodation of the mechanical loads acting on the vertebral column during locomotion. As such, epaxial muscles play a significant role in trunk support in terrestrial amniotes (Slijper, 1946; Kummer, 1959; Frey, 1988a, b; Salisbury and Frey, 2001). The role of epaxial musculature may have been particularly important in sauropod dinosaurs, due to their extraordinary lengths $(>20 \mathrm{~m})$ and correspondingly large body masses (Henderson, 2006). Although studies conducted over the last 30 years have increased our understanding of sauropod locomotor capabilities (e.g., Coombs, 1975; Coombs, 1978; Alexander, 1985; Christiansen, 1997; Bonnan, 2003, 2005; Carrano, 2005), soft-tissue reconstructions and functional morphology of the sauropod trunk are still widely neglected fields of research. The few studies on the biomechanics of sauropod vertebrae have focused on stress distribution in the sauropod vertebral column, proving a strong influence of the epaxial musculature on the stabilization of the dorsal vertebral column (Alexander, 1985; Henderson, 2004) and refuting a hypothetical tripodial feeding stance (Rothschild and Molnar, 2005). No detailed reconstructions of the epaxial musculature have been done to characterize the influence of these muscles on trunk support. Consequently, the variability in the epaxial trunk musculature and how it might relate to locomotor styles in different sauropod groups remains unknown. Whereas reconstructions of thoracic epaxial muscles in ornithischian dinosaurs are facilitated by the presence of ossified tendon systems (e.g., Norman, 1986; Organ, 2006), no such indications are available in dorsal vertebrae of sauropods. Additionally, the highly derived morphology of sauropod dorsal vertebrae makes comparisons with extant amniotes difficult.

The aim of this paper is to provide a hypothetical reconstruction of the thoracic epaxial muscles in diplodocid and dicraeo-

\footnotetext{
*Current address: Museum für Naturkunde der Humboldt-Universität zu Berlin, Invalidenstrasse 43, 10115 Berlin, Germany; d.schwarz-wings@ mfn-berlin.de
}

saurid sauropods based on the soft-tissue anatomy of extant crocodylians and birds, which can be used in future functional morphological analyses of the sauropod trunk. First, the general osteology of the trunk and thoracic epaxial muscles in extant crocodylians and birds is reviewed. This forms the basis for the Extant Phylogenetic Bracket-based soft-tissue reconstructions of diplodocid and dicraeosaurid sauropods. Next, the osteology of the axial skeleton of the trunk of diplodocid and dicraeosaurid sauropods is outlined, including a discussion of the still problematic reconstruction of rib articulation and its influence to the hypothetical cross-section of the trunk of these sauropods. The specific soft-tissue reconstructions rely on these preceding paragraphs of trunk osteology in sauropods and extant archosaurs. Last, the soft-tissue reconstructions are discussed in terms of their applicability for other eusauropods and of their implications for functional morphology of eusauropods.

Institutional Abbreviations-AMNH, American Museum of Natural History, New York City, U.S.A; CDUT, Chengdu University of Technology, Chengdu, China; CM, Carnegie Museum of Natural History, Pittsburgh, U.S.A.; HMN, Museum für Naturkunde der Humboldt-Universität zu Berlin, Berlin, Germany; IPFUB, Paleontology Section, Institute of Geological Sciences, Freie Universität Berlin, Berlin, Germany; IVPP, Institute of Vertebrate Paleontology and Paleoanthropology, Beijing, China; MACN, Museo Argentino de Ciencias Naturales, Buenos Aires, Argentina; NMB, Naturhistorisches Museum Basel, Basel, Switzerland; NSMT, National Sciences Museum Tokyo, Tokyo, Japan; YPM, Yale Peabody Museum, New Haven, U.S.A.; ZDM, Zigong Dinosaur Museum, Zigong, China.

\section{MATERIAL AND METHODS}

\section{Taxon Sampling and Material}

For a reconstruction of the thoracic epaxial musculature, detailed osteological information about the dorsal vertebral column, the dorsal ribs, the sacrum, and the ilium of the fossil under study is required. Diplodocid and dicraeosaurid sauropods comprise taxa with a very good record of the dorsal and pelvic 
anatomy and therefore have been used in this work to reconstruct thoracic epaxial muscles in sauropods. The following diplodocid and dicraeosaurid material used for the reconstructions was examined first hand.

Dicraeosauridae-Amargasaurus: The skeleton MACN-N 15 of $A$. cazaui comprises the presacral vertebral column, some isolated dorsal ribs, and the ilium (Salgado and Bonaparte, 1991). Dicraeosaurus: HMN "skeleton m" of D. hansemanni comprises the complete dorsal vertebral column with dorsal ribs, pelvis, and sacrum (Janensch, 1929; Janensch, 1961) and is taken as reference for the genus Dicraeosaurus. D. sattleri (Janensch, 1929) is excluded from the soft-tissue reconstructions because of its incomplete and fragmentary dorsal vertebrae and its uncertain taxonomic relationship (Salgado, 1999).

Diplodocidae-Apatosaurus: The skeleton of A. louisae (CM 3018) comprises dorsal vertebrae and ribs, sacral vertebrae, and an ilium (Gilmore, 1936) and is taken as reference for the genus Apatosaurus. Other specimens of A. louisae (e.g., AMNH 550, CM 563, YPM 1980), partial skeletons of A. excelsus (NSMT-PV 20375), and a partial skeleton of $A$. ajax (Upchurch et al., 2004b) resemble CM 3018 in their dorsal and sacral osteology and are also used for the soft-tissue reconstructions. Barosaurus: Two partial axial skeletons of B. lentus (YPM 429 and AMNH 6341) (Lull, 1919; McIntosh, 2005) have been used as a reference for Barosaurus. However, both specimens are preserved with incomplete dorsal ribs, which makes a precise reconstruction of the dorsal cross-section and the rib cage impossible. Diplodocus: Two partial skeletons of $D$. carnegii include a complete dorsal series with dorsal ribs (CM 84, CM 94), sacrum, and ilium (CM 94) (Hatcher, 1901; McIntosh, 1981). Many further dorsal and sacral elements of different species of Diplodocus resemble CM 84/CM 94 in their dorsal and sacral osteology (e.g., AMNH FR 223, partial skeleton of D. longus).

Because of their incomplete preservation or a lack of a detailed description, neither the dicraeosaurid Brachytrachelopan nor the diplodocids Dinheirosaurus and Tornieria were included into the soft-tissue reconstructions. The following material of non-diplodocoid sauropods, which is relevant for the discussion in this work, has been examined personally for comparison and further discussion: Shunosaurus lii (ZDM 5008, ZDM T5401, IVPP no collection number available); Camarasaurus lentus (CM 11338, CM 11393), Camarasaurus grandis (YPM 1900, 1901, YPM 1908), Camarasaurus supremus (AMNH FR 5760); Haplocanthosaurus priscus (CM 572), Haplocanthosaurus utterbacki (CM 879).

\section{Extant Material Examined for Comparison}

The skeletons of the crocodylomorphs Crocodylus porosus (IPFUB OS 13) and Tomistoma schlegeli (NMB, no collection number) were examined. The trunk of Paleosuchus palpebrosus was dissected. Skeletons of the birds Rhea americana (NMB 2670), Struthio camelus (NMB 8180), Dromaius novaehollandiae (NMB 2978), Casuarius casuarius (NMB 1829), Sarcoramphus gryphus (NMB 3295), and Cygnus cygnus (NMB 10588) were examined for comparison. The trunks of Columba livia and Ardea cinerea were dissected.

\section{Methods}

For the reconstruction of the thoracic epaxial muscles of sauropods, topographic indicators of muscle attachment sites are used in the context of an Extant Phylogenetic Bracket (EPB) approach (Bryant and Russell, 1992; Witmer, 1995, 1997). The phylogenetic position of Sauropodomorpha within Saurischia is robustly supported (e.g., Gauthier, 1986; Sereno, 1999), thus enabling the application of the EPB approach for soft tissue reconstructions in sauropods using Crocodylia and Aves as bracketing groups that provide the anatomical framework for such reconstructions. Epaxial muscles and ligaments often leave characteristic traces (= osteological correlates, Witmer, 1995) on the surface of the vertebrae of avians and crocodylians. If such osteological correlates are present on vertebrae of sauropods, similar muscles can be reconstructed confidently. However, variation in the soft tissue configuration of extant counterparts and uncertainties in the interpretation of osteological correlates requires a cautious approach in reconstructing soft tissue anatomy of extinct taxa (Bryant and Russell, 1992; Witmer, 1995; Carrano and Hutchinson, 2002).

As a means for evaluating the level of confidence of reconstructions based on an EPB approach, three levels of inference have been introduced (Witmer, 1995, 1997). A Level I inference refers to a situation in which a homologous soft tissue is present in both the two extant bracketing taxa, and its osteological correlate is observed in these bracketing taxa plus the fossil taxon of interest. This case provides unequivocal support for the presence of the soft structure in this fossil taxon. If this structure provides no osteological correlates in extant bracketing taxa, its reconstruction in the fossil would be a Level I' inference. A Level II inference occurs if only one of the two extant outgroups possesses a soft tissue structure with an osteological correlate, and when the latter is found in the fossil taxon. Correspondingly, a Level II' inference refers to the same structure that leaves no osteological evidence. A Level III inference is made if a structure is not present in either extant outgroups. These levels of inference are used here regarding the reconstructed presence or absence of specific muscle groups in sauropods, as well as for the reconstruction of their attachment areas.

The designation of higher taxa in this study is adopted from the crown clade names for Sauria (= extant Diapsida) (Gauthier et al., 1988), and phylogenetic taxonomy for sauropods is based on Wilson (2002) and Curry Rogers (2005). Diplodocidae and Dicraeosauridae are monophyletic groups that together with Suuwassea form the clade Flagellicaudata (Harris and Dodson, 2004; Harris, 2006). The anatomical nomenclature is adopted from Frey (1988a) and Tsuihiji (2005) for myology and from Baumel et al. (1993) and Wilson (1999) for osteology. The hypothesized homology of $\mathrm{m}$. transversospinalis in extant Sauria follows Tsuihiji (2005), and that of thoracic epaxial muscles of extant Archosauria follows Organ (2006) (Table 1).

TABLE 1. Homologies between thoracic epaxial muscles of Crocodylia and Aves as inferred by Tsuihiji (2005) and Organ (2006).

\begin{tabular}{|c|c|}
\hline Crocodylia & Aves \\
\hline $\begin{array}{l}\text { mm. interspinales } \\
m m . \text { interarticulares }\end{array}$ & mm. intercristales \\
\hline $\begin{array}{l}\text { m. transversospinalis, medial part with } 3 \text { series of tendons: } \\
\text { m. multifidus }\end{array}$ & m. longus colli dorsalis, pars thoracica with $2-4$ series of tendons: \\
\hline m. spinalis & m. longus colli dorsalis, pars thoracica, medial part \\
\hline m. articulospinalis & m. longus colli dorsalis, pars thoracica, lateral part \\
\hline m. transversospinalis, lateral part: m. tendinoarticularis & m. ascendentes thoracicus \\
\hline m. longissimus dorsi & "m. iliocostalis", craniodorsal part \\
\hline m. iliocostalis & "m. iliocostalis", caudoventral part \\
\hline
\end{tabular}




\section{THE THORACIC EPAXIAL MUSCLES IN DIPLODOCID AND DICRAEOSAURID SAUROPODS}

\section{Configuration and Homology of Thoracic Epaxial Musculature in Extant Archosauria}

The thoracic epaxial musculature of extant Amniota is divided into three major groups extending parallel to each other along the long axis of the vertebral column (e.g., Vallois, 1922; Kardong, 1998). From medial to lateral, these are the m. transversospinalis, $\mathrm{m}$. longissimus, and $\mathrm{m}$. iliocostalis groups, which are closely associated with the neural spines, transverse processes, and dorsal ribs, respectively (Slijper, 1946; George and Berger, 1966; Gasc, 1981; Frey, 1988a; Kardong, 1998). Each muscle group can be distinguished by its size, proportions, and internal tendon configuration.

Crocodylia-Extant crocodylians possess 15 dorsal vertebrae, and in all but the first two the parapophyses and diapophyses lie together on the straight, laterally-directed transverse process (Hoffstetter and Gasc, 1969). The width of the transverse processes increases from the dorsal 3 to 7 , reaching a maximum of 1.8 times of the width of the vertebral body, and then decreases to the same width as the vertebral body (Frey, 1988a). Dorsals 3 to 15 have tall neural spines of uniform height that are approximately 1.5 times the height of the vertebral body (Frey, 1988a). The dorsal ribs are conspicuously curved in the transverse plane and caudolaterally oriented, which results in a transversely oval cross-section of the trunk. Dorsally, the trunk is covered by four longitudinal rows of paravertebral osteoderms, lateral to which several longitudinal rows of accessory osteoderms attach (Wettstein, 1937). The only exception to this is Gavialis gangeticus, which possesses only the paravertebral osteodermal rows. The paravertebral osteoderms are tightly connected to the underlying thoracic epaxial musculature, whereas the accessory osteoderms are anchored in the dermis, separated from the underlying muscles by a layer of retinaculum (Seidel, 1979; Frey, 1988a; Salisbury, 2001; Salisbury and Frey, 2001).

The thoracic epaxial muscles and paravertebral osteoderms are connected by ligamentum cingulatum, which continues from the apices of the neural spines laterally along the contact zone between two adjacent transverse rows of paravertebral osteoderms (Fig. 1). Tendons and myosepta of the m. transversospinalis group and $\mathrm{m}$. longissimus dorsi both attach to this ligament and the internal face of the corresponding osteoderm. The myosepta of $\mathrm{m}$. iliocostalis are connected to ligamentum cingulatum at the lateral margin of the lateralmost paravertebral osteoderm. In transverse cross-section, the thoracic epaxial musculature of extant crocodylians extends from the lateral face of the neural spines to the distal end of the dorsal ribs (Fig. 1E). M. transversospinalis has approximately the same cross-sectional area as the laterally adjacent $\mathrm{m}$. longissimus dorsi. The lateralmost part of the epaxial muscles, m. iliocostalis, covers and attaches to the dorsal ribs. Most of the mass of $\mathrm{m}$. iliocostalis is positioned lateral to the vertebral column, due to the transverse orientation of the dorsal ribs (Fig. 1E).

M. transversospinalis is divided into four sub-units that are arranged mediolaterally. The space immediately lateral to the neural spines is occupied by $\mathrm{m}$. multifidus $(=\mathrm{m}$. neurospinalis dorsi, Vallois, 1922; Tsuihiji, 2005) and m. spinalis (= m. spinoarticularis dorsi, Vallois, 1922; Tsuihiji, 2005). M. articulospinalis extends up to the zygapophyseal capsules. These three medial sub-units of $\mathrm{m}$. transversospinalis (Table 1) are separated from the laterally positioned $\mathrm{m}$. tendinoarticularis by a distinct septum (Fig. 1). M. tendinoarticularis is either regarded as an autonomous muscle (Hair, 1868; Frey, 1988a; Salisbury, 2001), or as part of the m. transversospinalis group (Gasc, 1981; Bornhauser and Ziswiler, 1983; Tsuihiji, 2005; Organ, 2006). The latter hypothesis (Table 1) is supported by the innervation pattern of the epaxial muscles in the trunk (Murakami et al., 1991). A deep medial sub-unit of $\mathrm{m}$. transversospinalis, consisting of mm. interspinales and mm. interarticulares is present (Vallois, 1922; Gasc, 1981; Tsuihiji, 2005; Organ, 2006). M. longissimus dorsi is separated from $\mathrm{m}$. transversospinalis by the septum intermusculare dorsi, and from the laterally positioned $\mathrm{m}$. iliocostalis by the septum transversum (Fig. 1).

Aves-Extant avians have a very short trunk, and the dorsal and sacral vertebral column is characterized by strong intervertebral fusion. There are only four to six "free" dorsal vertebrae, bearing dorsal ribs that articulate with the sternum (George and Berger, 1966). The cranialmost dorsal vertebrae often fuse to form a notarium. Although caudal dorsal and sacral vertebrae fuse into a synsacrum, the caudal dorsal vertebrae can still bear dorsal ribs, which lie medial to the ilium (Bellairs and Jenkins, 1960; George and Berger, 1966). In the dorsal vertebrae of extant avians, the parapophyses lie at the base of the neural arch (Bellairs and Jenkins, 1960; George and Berger, 1966; Baumel and Witmer, 1993), whereas the diapophyses form laterally directed transverse processes that can bow very slightly dorsally. The width of the transverse processes increases caudally. The lateralmost third of the transverse process is slightly or strongly beveled ventrolaterally and bears a roughened dorsal surface. The neural spines increase in height slightly from cranial to caudal and are approximately as high as the vertebral bodies. The dorsal ribs of avians are often curved in their proximal quarter (e.g., Sarcorhamphus, Cygnus), but straight throughout the remainder of their length. In articulation, the dorsal ribs are caudoventrally oriented, which results in a high-oval cross-section of the trunk (Fig. 1F).

The thoracic epaxial muscle groups of avians are strongly interwoven and merge into each other, complicating the separation and determination of homology of single muscles. In transverse cross-section, the epaxial musculature of avians fills the space between the lateral surface of the neural spines, the dorsal surface of the transverse processes, and the proximal fourth of the length of the dorsal ribs. The height of the epaxial musculature above the transverse processes decreases laterally (Fig. 1). The combined mass of m. longus colli thoracicus and $\mathrm{m}$. ascendens thoracicus is significantly larger in cross-section than the mass of $\mathrm{m}$. iliocostalis. M. iliocostalis lies with its crosssection laterally to the vertebral centra. The dorsal vertebrae of extant Aves are pneumatized, with pneumatic diverticula accumulating around the transverse processes and intermingling with the thoracic epaxial muscles (Duncker, 1971; O'Connor, 2004).

The m. transversospinalis group in extant Aves is separated from the laterally adjacent m. iliocostalis (Zusi and Bentz, 1984) by means of a strong fascia, aponeurosis transversa, which inserts at the lateral edges of the transverse processes of the dorsal vertebrae and is regarded as being homologous to septum intermusculare dorsi (Tsuihiji, 2005). The muscles lying just medial to the aponeurosis transversa are $\mathrm{m}$. longus colli dorsalis, pars thoracica and $\mathrm{m}$. ascendentes thoracicus (Table 1, Fig. 1). Due to their common innervation pattern and their position on the vertebrae, both muscles are regarded as sub-units of m. transversospinalis (Tsuihiji, 2005). The medialmost tendon series of $\mathrm{m}$. longus colli dorsalis, pars thoracica is homologous to $\mathrm{m}$. spinalis, and the laterally following tendon series to $\mathrm{m}$. articulospinalis in extant Crocodylia (Tsuihiji, 2005; Organ, 2006). M. ascendentes thoracicus is homologous to $\mathrm{m}$. tendinoarticularis in extant Crocodylia (Table 1). A medial, deep sub-unit of $\mathrm{m}$. transversospinalis is represented by $\mathrm{mm}$. intercristales plus mm. interspinales (Tsuihiji, 2005; Organ, 2006). In extant avians, $\mathrm{m}$. iliocostalis lies directly laterally adjacent to $\mathrm{m}$. ascendentes thoracicus. The sub-division of $\mathrm{m}$. iliocostalis into two separate tendinous systems (Fig. 1D) and its innervation pattern indicate that it also incorporates $\mathrm{m}$. longissimus dorsi (Tsuihiji, 2005; Organ, 2006). 

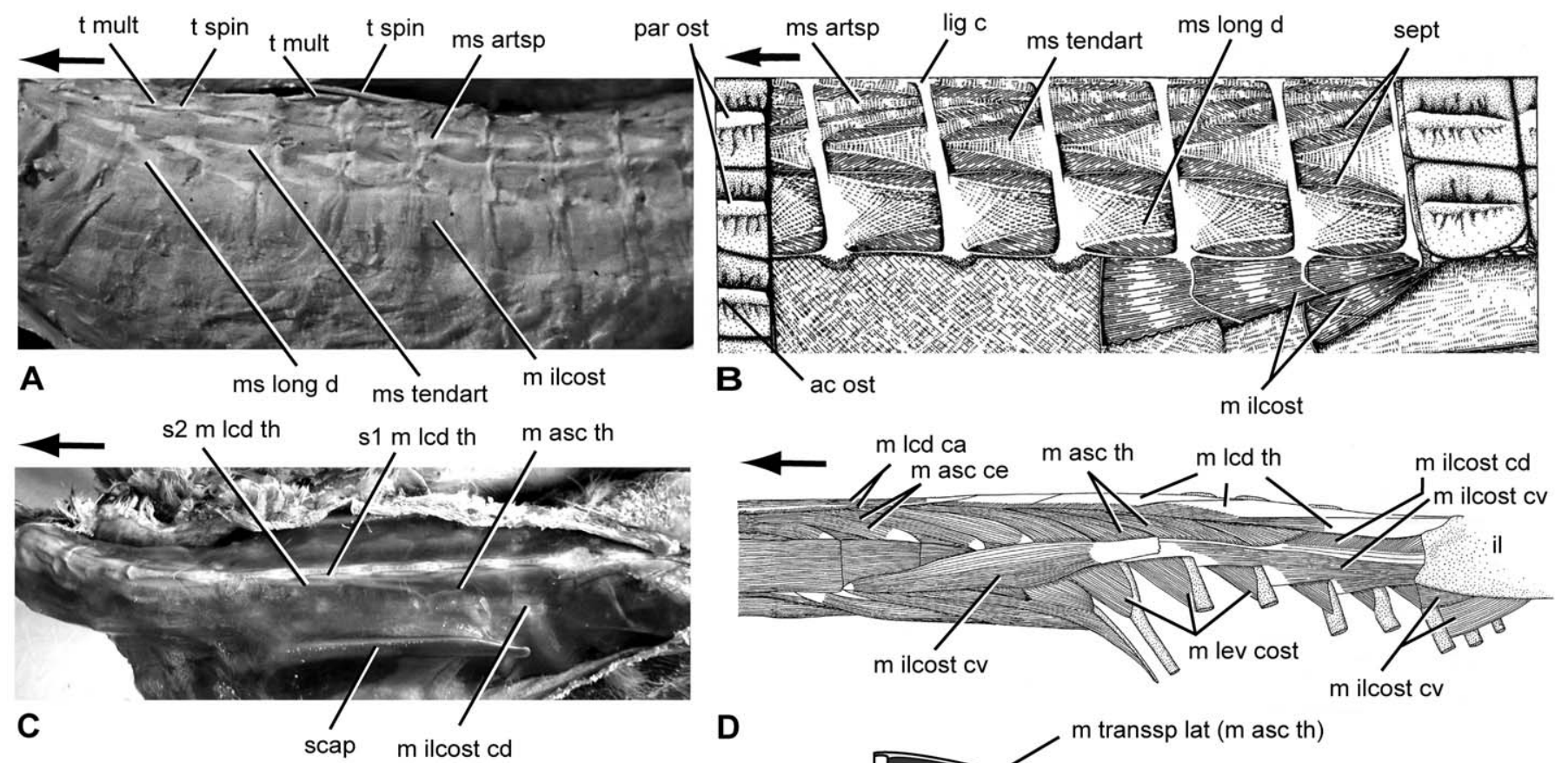

D

$\mathrm{m}$ ilcost cv

$m$ transsp med ( $m$ mult, $m$ spin \& $m$ artspin)

$m$ transsp lat ( $m$ tendart)

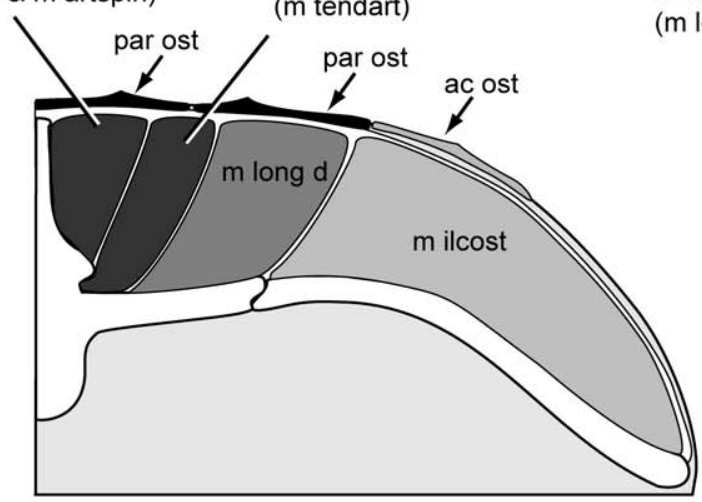

E m transsp med ( $\mathrm{m}$ lcd th)

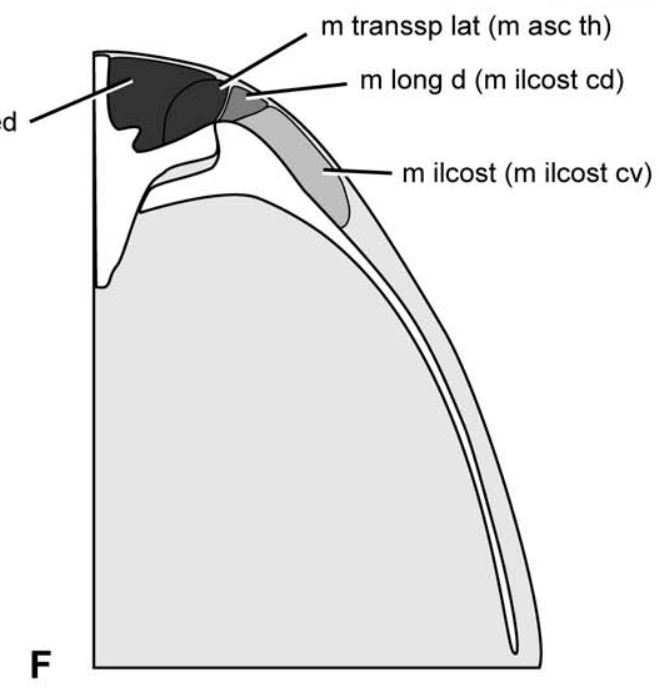

FIGURE 1. Thoracic epaxial musculature in extant Crocodylia and Aves. A, photograph of thoracic epaxial musculature of the crocodylian Paleosuchus palpebrosus in left lateral view; note that osteodermal armor has been removed. B, diagram of thoracic epaxial musculature of Alligator mississippiensis, modified from Frey (1988a: Fig. 55). C, photograph of thoracic epaxial musculature of the bird Ardea cinerea in left dorsolateral view. The epaxial musculature is bounded laterally by the scapula and its musculature. D, diagram of thoracic epaxial musculature of Grus americana, modified from Fisher \& Goodman (1955: Fig. 37); E, schematic cross-section of the dorsal part of the trunk of Crocodylus porosus at the seventh dorsal vertebra; F, schematic cross-section of the dorsal part of the trunk of Rhea americana at the fifth dorsal vertebra. Abbreviations: ac ost, accessory osteoderm; lig $\mathbf{c}$, ligamentum cingulatum; $\mathbf{m}$ artsp, $\mathrm{m}$. articulospinalis; $\mathbf{m}$ asc ce, $\mathrm{m}$. ascendens cervicalis; $\mathbf{m}$ asc th, $\mathrm{m}$. ascendens thoracicus; $\mathbf{m}$ ilcost, $\mathrm{m}$. iliocostalis; $\mathbf{m}$ ilcost $\mathbf{c v}, \mathrm{m}$. iliocostalis, caudoventral division; $\mathbf{m}$ ilcost $\mathbf{c d}, \mathrm{m}$. iliocostalis, craniodorsal division; $\mathbf{m}$ lcd ca, $\mathrm{m}$. longus colli dorsalis, pars caudalis; $\mathbf{m}$ led th, $\mathrm{m}$. longus colli dorsalis, pars thoracica; $\mathbf{m}$ lev cost, $\mathrm{m}$. levator costarum; $\mathbf{m}$ long $\mathbf{d}$, $\mathrm{m}$. longissimus dorsi; $\mathbf{m}$ mult, m. multifidus; $\mathbf{m}$ spin, $\mathrm{m}$. spinalis; $\mathbf{m}$ tendart, $\mathrm{m}$. tendinoarticularis; $\mathbf{m}$ transsp lat, lateral part $\mathrm{of} \mathbf{m}$. transversospinalis; $\mathbf{m}$ transsp med, medial part of $\mathrm{m}$. transversospinalis; ms artsp, myoseptum of $\mathrm{m}$. articulospinalis; ms long d, myoseptum of m. longissimus dorsi; ms tendart, myoseptum of m. tendinoarticularis; par ost, paravertebral osteoderm; $\mathbf{s} \mathbf{~ m}$ led th, $1^{\text {st }}$ tendon series of $\mathbf{m}$. longus colli dorsalis, pars thoracica; $\mathbf{s} \mathbf{~ m}$ led th, $2^{\text {nd }}$ tendon series of $\mathrm{m}$. longus colli dorsalis, pars thoracica; scap, scapula; sept, bounding septum; $\mathbf{t}$ mult, tendon of $\mathrm{m}$. multifidus; $\mathbf{t}$ spin, tendon of m. spinalis. Arrows indicate cranial direction.

Trunk Shape, Rib Articulation, and Epaxial Musculature in Diplodocidae and Dicraeosauridae

The number of dorsal vertebrae is 12 or 13 in Dicraeosaurus (Janensch, 1929), 10 in Amargasaurus (Salgado and Bonaparte, 1991), Diplodocus (Hatcher, 1901), and Apatosaurus (Upchurch et al., 2004b), and 9 in Barosaurus (Upchurch et al., 2004a; McIntosh, 2005). The parapophyses lie on the neural arch cra- nioventral to or on the transverse process. The actual transverse process is formed by the diapophyses. The transverse processes are wider in the cranial half of the dorsal series than in its caudal half. In Dicraeosauridae, the transverse processes are maximum 1.2 times as wide as the vertebral bodies, strongly dorsally directed, and laterally rugose (Fig. 2). With a height of 2.5 times (Dicraeosaurus) or 3.5 times (Amargasaurus) the height of the vertebral bodies, the dorsal neural spines of Dicraeosauridae are 
tallest among sauropod dinosaurs (Fig. 2). The neural spines in the trunk of Dicraeosaurus are of uniform height throughout the trunk. In contrast, those of Amargasaurus increase in height in sacral direction, reaching a maximum at the sacral vertebrae.
The neural spines are deeply bifurcate until the seventh (Dicraeosaurus) or the ninth (Amargasaurus) dorsal vertebra. The neural spines that follow these are unbifurcated, broad, and petal-shaped (Fig. 2D).
A

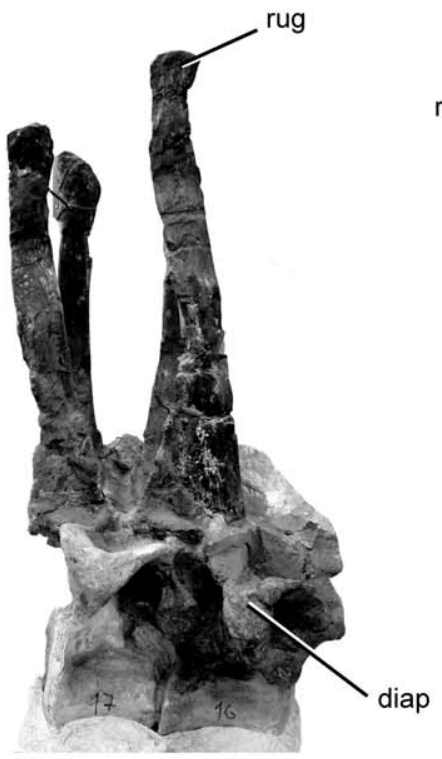

B

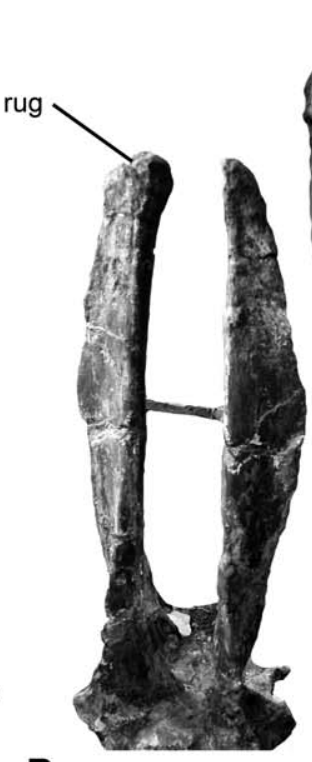

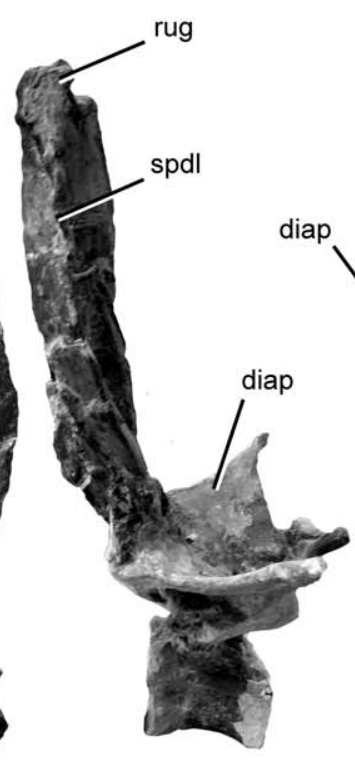

C

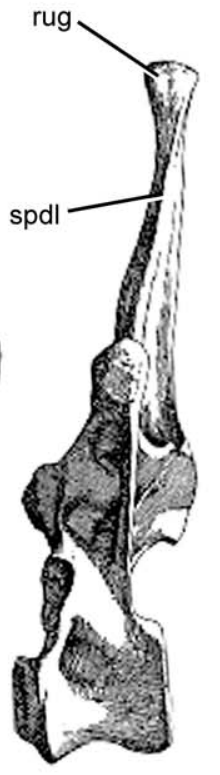

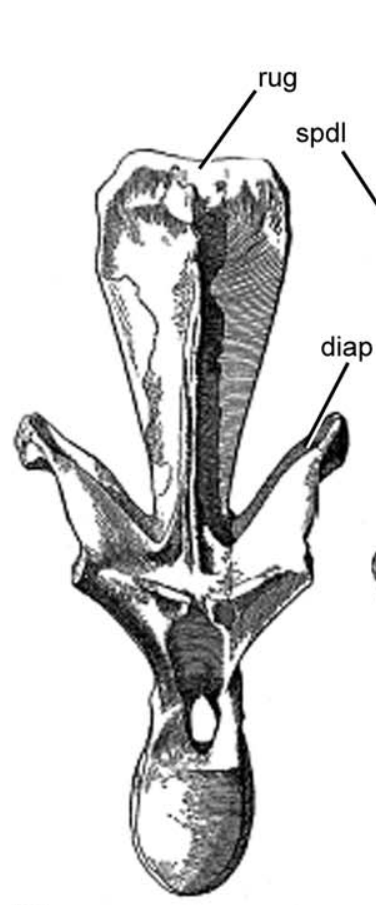

D

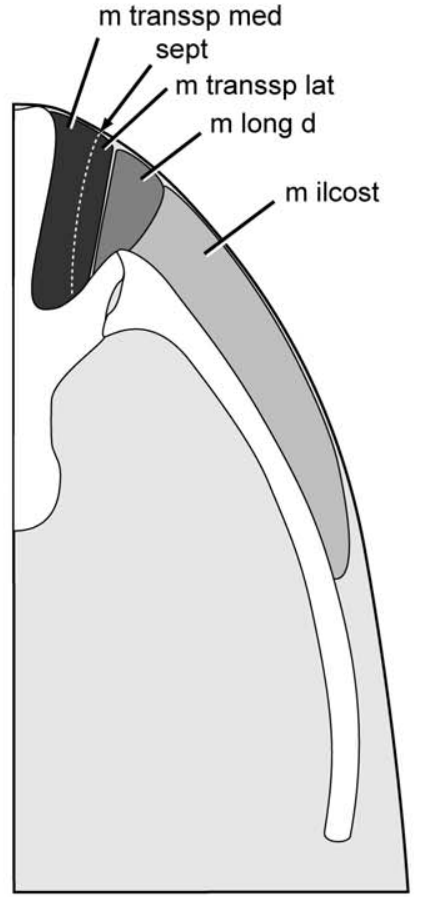

E

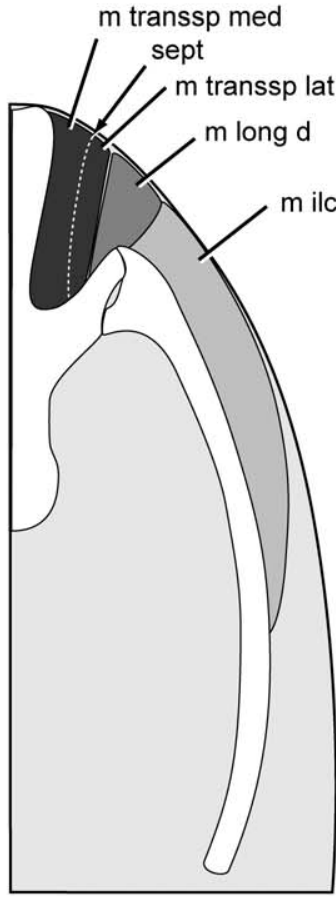

$m$ transsp med m transsp med m transsp med

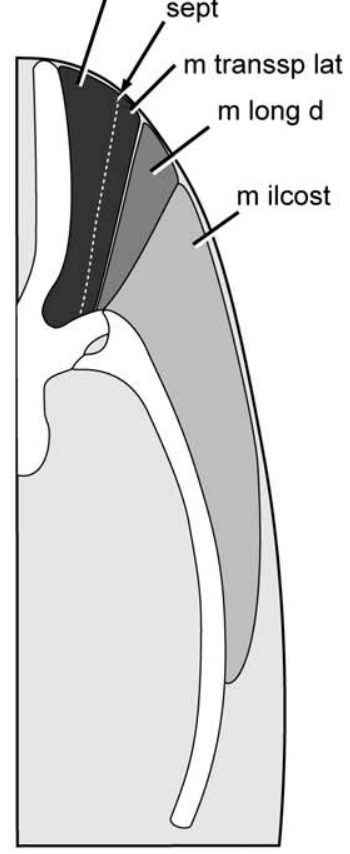

F

FIGURE 2. Thoracic epaxial musculature in Dicraeosauridae. A-D, dorsal vertebrae and osteological correlates for thoracic epaxial musculature. A, dorsals 4-5 of Amargasaurus cazaui in right lateral view. B, dorsal 7 of same in cranial (left) and right lateral (left) views. C, dorsal 4 of Dicraeosaurus hansemanni, from Janensch (1929: pl 1) in cranial (left) and left lateral (right) views. D, dorsal 8 of same in cranial (left) and right lateral (right) views. Scale bar equals $10 \mathrm{~cm}$. E-F, cross-sections of the dicraeosaurid trunk with reconstructed thoracic epaxial muscles. E, Dicraeosaurus hansemanni, reconstruction with lateroventrally inclined (left) and caudoventrally inclined (right) dorsal ribs. Different inclinations of the dorsal ribs affect vertical orientation of $\mathrm{m}$. iliocostalis and its distance to the vertebrae; $\mathbf{F}$, Amargasaurus cazaui with caudoventrally inclined dorsal rib. Not to scale. Abbreviations: diap, diapophysis; $\mathbf{m}$ ilcost, $\mathrm{m}$. iliocostalis; $\mathbf{m}$ long $\mathbf{d}$, $\mathrm{m}$. longissimus dorsi; $\mathbf{m}$ transsp lat, lateral part of $\mathrm{m}$. transversospinalis; m transsp med, medial part of m. transversospinalis; rug, rugosity; sept, bounding septum; spdl, spinodiapophyseal lamina. 
In Diplodocidae, the transverse processes are horizontally directed, and their width does not exceed that of the vertebral bodies. The lateral part of the transverse processes of the cranial five (Diplodocus, Apatosaurus) or four (Barosaurus) dorsal vertebrae is ventrolaterally beveled (Fig. 3). The lateral third of the transverse processes is covered by an irregular, roughened bone texture. The dorsal neural spines increase in height from cranially to caudally, and reach a maximum of two times of the height of the vertebral bodies. The first three dorsal vertebrae of Apatosaurus, the first four dorsal vertebrae of Barosaurus, and the first five dorsal vertebrae of Diplodocus are deeply bifurcated (Fig. 3).

The dorsal ribs in the cranial and medial trunk region of diplodocids and dicraeosaurids are straight in their proximal half and curve slightly medially in their distal half. In the caudalmost four or five dorsal ribs, the whole rib body is medially curved with a convex lateral and a concave medial edge. With the diapophyses being very often distorted or crushed, and virtually no sauropod skeletons having been found with their dorsal ribs preserved in situ and articulated, the reconstruction of the ribvertebra articulation is difficult. Even in the case of well preserved skeletons, the inclination with which the rib projects lateroventrally and caudally from its articulation point at the vertebra cannot be reconstructed precisely from the articular surface of the diapophysis and parapophysis alone. In many reconstructions and mounts, the dorsal ribs are positioned extending from the diapophyses and parapophyses relatively straight ventrolaterally, which results in an incomplete articulation of tuberculum/diapophysis and capitulum/parapophysis, a laterally broad rib cage, and a barrel-shaped torso. The recently discovered skeleton of the dicraeosaurid Brachytrachelopan has an articulated ribcage, in which the dorsal ribs are inclined caudally from their articulation at the diapophysis (Rauhut et al., 2005). The position of the ribs in articulation with the corresponding parapophyses and diapophyses and the undisturbed preservation of the thorax indicate that the 'true' position of the ribs might have been preserved. The find is consistent with a study of Camarasaurus, which uses as criteria for the rib articulation the closest match of the tuberculum/diapophysis and capitulum/parapophysis articulation and a lateral orientation of the flattened rib head, resulting similarly in caudally inclined dorsal ribs (Wood, 2006). For both taxa, the caudoventral inclination of the dorsal ribs results in a narrow trunk cross-section that tapers ventrally. Taking into account these results, the crosssection of the trunk of Diplodocidae and Dicraeosauridae was generated under the assumption of caudoventrally inclined dorsal ribs, which allows a close match between tuberculum/ diapophysis and capitulum/parapophysis. In cranial view, the orientation of the ribs is vertical. The overall length of the ribs, and the curvature of the rib body leads to a narrow and highoval cross-section of the trunk, with sloping dorsolateral flanks.

Based on comparison with Crocodylia and Aves, the thoracic epaxial musculature of diplodocids and dicraeosaurids most likely extended in cross-section from the lateral face of the neural spines to the dorsal face of the transverse processes and at least the dorsal half of the dorsal ribs. Diplodocid and dicraeosaurid sauropods have narrow transverse processes (see above) divided into a smooth medial and a roughened lateral part, which suggests a division of the muscle mass covering the transverse processes. A roughened lateral part of the transverse processes characterizes the insertion area of $\mathrm{m}$. longissimus dorsi in extant Crocodylia and Aves (see below). Consequently, the larger medial part of the transverse processes of Diplodocidae and Dicraeosauridae would have served as attachment area for m. transversospinalis, whereas the roughened lateral part would belong to $\mathrm{m}$. longissimus dorsi (Figs. 2, 3, [Level I inference]). It is likely that $\mathrm{m}$. transversospinalis of Diplodocidae and Dicraeosauridae was divided into a medial and a lateral part (comprising each a separate tendon series) along the zygapophyseal capsules or the mid-width of the transverse processes, as this occurs in extant crocodylians and avians (Table 1, Level I inference). The decrease in width of the transverse processes caudally would result in a decrease in the width of $\mathrm{m}$. transversospinalis towards the sacrum. The small area of the lateral roughness of the transverse processes indicates that $\mathrm{m}$. longissimus dorsi of diplodocid and dicraeosaurid sauropods might have been restricted to the lateralmost, rugose part of the transverse processes like in avians (Figs. 2, 3). Because of the orientation of the dorsal ribs in a vertical plane in cranial view, $\mathrm{m}$. iliocostalis of Diplodocidae and Dicraeosauridae had a vertical orientation and would have extended with its mass over most of the height of the vertebral column as well as ventral to it (Figs. 2, 3).

In the reconstructed cross-section, the lateral contour of the body and therefore also the extension of the epaxial muscles towards the exterior cannot be determined precisely, because there is no osteological restriction. Consequently, the size of the cross-sections of the epaxial muscles cannot be determined precisely by the preserved fossil evidence. The remarkable height of the neural spines in the trunk of dicraeosaurids might have resulted, together with the strongly dorsally inclined transverse processes, in a high but in comparison with diplodocids more narrow cross-section of the thoracic epaxial muscles (Figs. 2, 3). As alternative models with different rib inclinations show (see Figs. 2, 3), the inclination of the dorsal ribs influences the cross-section and vertical orientation of $\mathrm{m}$. iliocostalis both in Diplodocidae and Dicraeosauridae: in the model with the caudoventrally inclined dorsal ribs, $\mathrm{m}$. iliocostalis is lateromedially more narrow in cross-section and stronger vertically oriented than in the model with lateroventrally inclined dorsal ribs.

\section{Deep Layer of M. transversospinalis Group}

Crocodylia-Mm. interspinales connect consecutive neural spines with each other by short, longitudinal muscle fibers (Gasc, 1981; Tsuihiji, 2005; Organ, 2006). The muscle inserts on the cranial and caudal margins of the neural spines, where the transition between the laminae spinosae and the neural spine often forms a shallow depression. Muscle fibers of $\mathrm{mm}$. interarticulares originate from the base of the neural spine and the cranial face of the postzygapophyses and extend from there cranially to the caudal face of the cranially adjacent postzygapophyses. A thin lateral series originating from the cranial face of the prezygapophyses and proceeding cranially along two vertebrae to the postzygapophyses was described by Tsuihiji (2005).

Aves-In extant avians, the serial $\mathrm{mm}$. intercristales consist of slips that originate at the base of the neural spine and the cranial face of the postzygapophysis, and proceed cranially to attach at the caudal tip of the next cranial postzygapophysis (e.g., Tsuihiji, 2005). Mm. intercristales are interwoven with the overlying $\mathrm{m}$. longus colli dorsalis, pars thoracica (Landolt and Zweers, 1985; Tsuihiji, 2005). Mm. interspinales are very weakly developed as a thin sheet overlying the thoracic interspinal ligament (Tsuihiji, 2005; Organ, 2006). Mm. interspinales muscle fibers originate from the cranial edge of the neural spines and insert at the caudal edge of the cranially adjacent neural spine (Organ, 2006). In birds possessing a notarium, this muscle is absent (Organ, 2006).

Diplodocidae and Dicraeosauridae - In Diplodocidae and Dicraeosauridae, there is no osteological correlate on neural spines or the pre- and postzygapophyses for the attachment of a deep layer of $\mathrm{m}$. transversospinalis. Nevertheless, the presence of a deep layer of $\mathrm{m}$. transversospinalis in Aves and Crocodylia makes it parsimoniously plausible that a similar muscle existed in these sauropods and inserted in similar areas (Level I' inference). If so, parts of the deep layer of m. transversospinalis would have extended between the postzygapo- 
physes of adjacent dorsal vertebrae as in extant archosaurs (Table 2), whereas other parts similar to $\mathrm{mm}$. interspinales of birds and crocodylians would have extended between the subsequent neural spines and directly laterally to the interspinal ligaments. Because $\mathrm{mm}$. interspinales are virtually the only muscles that extend between longitudinally following neural spines of birds and crocodylians, it is possible that the undivided, transversely broad and "petal"-shaped caudal dorsal neural spines of Dicraeosauridae provided a large area for insertion of these muscles. It is therefore likely that $\mathrm{mm}$. interspinales of Dicraeosauridae would have been significantly larger in cross-section than in Diplodocidae, extant crocodylians, and avians.

\section{Superficial Layer of M. transversospinalis Group}

Crocodylia-M. multifidus and $\mathrm{m}$. spinalis comprise a serial, lattice-like tendon system along the lateral faces of the neural spines. Tendons of $\mathrm{m}$. multifidus originate at the caudodorsal edge of the lateral face of the neural spines and proceed at an angle of $5^{\circ}$ caudoventrally (Fig. 1A). Tendons of $\mathrm{m}$. spinalis originate craniodorsally on the lateral face of the neural spines and are inclined at the same angle as $\mathrm{m}$. multifidus cranioventrally (Hair, 1868; Gasc, 1981; Frey, 1988a; Tsuihiji, 2005). Fleshy parts of $\mathrm{m}$. multifidus insert on the lateral face of the neural spines, the medialmost part of the neural arch, and the dorsal aspect of the articular capsule of the zygapophyses. Fleshy parts of $\mathrm{m}$. spinalis insert laterally at the $\mathrm{m}$. multifidus tendons, the base of the neural spine, the medialmost part of the neural arch and the articular capsules of the zygapophyses (Frey, 1988a; Tsuihiji, 2005). The tendons of $\mathrm{m}$. spinalis are twisted laterally at their cranioventral extent, causing the tendon-muscle fiber complex to form a spiral (Frey, 1988a). Both m. multifidus and $\mathrm{m}$. spinalis are connected to ligamentum cingulatum and the paravertebral osteoderms via the apices of the neural spines.

M. articulospinalis comprises more fleshy than tendinous parts (Frey, 1988a). The tendons of $\mathrm{m}$. articulospinalis form at their origin dorsoventrally flattened and transversely broadened aponeuroses, which bifurcate cranially into a medial and a lateral branch (Fig. 1A, B). The medial branch of an aponeurosis originates from ligamentum cingulatum and the internal face of the medialmost paravertebral osteoderms and is connected to the caudolateral edge of the neural spines. The lateral branch is connected to the myoseptum of the laterally adjacent $\mathrm{m}$. tendinoarticularis (Frey, 1988a; Tsuihiji, 2005; Organ, 2006). The tendons of $\mathrm{m}$. articulospinalis run with an angle of $5^{\circ}$ from dorsal in a caudoventral direction. M. articulospinalis inserts with muscle fibers laterally at the roof of the neural arches and the dorsal aspect of the postzygapophyses. The caudal surface of the postzygapophyses is strongly rugose with some transverse striae marking these insertions. M. articulospinalis also inserts laterally at the $\mathrm{m}$. spinalis tendons, both muscles forming a closely bound mesh of interdigitating fibers (Frey, 1988a; Organ, 2006). M. articulospinalis is laterally bounded by a thin septum, which inserts along the lateral margins of the zygapophyseal capsules and the neural arches (Frey, 1988a; Murakami et al., 1991; Tsuihiji, 2005).

M. tendinoarticularis occupies the medial third of the width of the transverse processes (Fig. 1E) and is organized in complex myosepta, which extend caudodorsally to cranioventrally (Fig. 1A, B). In dorsal view, the myosepta are transversely broadened and triangular at their origination, but continue with a vertically directed lamina cranioventrally. The myosepta are dorsally attached to ligamentum cingulatum and the internal face of the medial and lateral paravertebral osteoderm. Muscle fibers emanate from the whole surface of the myosepta. At their cranioventral end, the myosepta are frayed and slightly twisted medially (Frey, 1988a), and insert by muscle fibers at the roof of the neural arch and the base of the transverse processes. Laterally, $\mathrm{m}$. tendinoarticularis is separated from $\mathrm{m}$. longissimus dorsi by septum intermusculare dorsi (Frey, 1988a; Tsuihiji, 2005), which is formed by the walls of the myosepta of $\mathrm{m}$. longissimus dorsi (Frey, 1988a). Openings in the ventral part of this bounding septum allow muscle fibers of $\mathrm{m}$. tendinoarticularis and $\mathrm{m}$. longissimus dorsi to interweave.

Aves-M. longus colli dorsalis, pars thoracica consists of a series of tendons and aponeuroses that together with associated muscle fibers connect neural spines with the postzygapophyses and also connect among each other (George and Berger, 1966; Zusi and Bentz, 1984; Tsuihiji, 2005). The muscle occupies the space between the neural spines and the zygapophyseal capsules, and the medial half to two-thirds of the transverse processes, lying medially and dorsally to $\mathrm{m}$. ascendentes thoracicus (Fig. 1C, D). The origin of the medialmost, first tendon series of $\mathrm{m}$. longus colli dorsalis, pars thoracica is the craniodorsal edge of the neural spines, from which the tendons proceed cranioventrally to insert caudally at the postzygapophyses and on the roof of the neural arch. Muscle fibers arising from these tendons attach laterally to the neural spines and interweave with the laterally adjacent second tendon series. The second tendon series originates at the caudodorsal edge of the neural spines and extends caudoventrally with the fleshy fibers inserting on the lateral face of the neural spines, the dorsal face of the postzygapophyses, and the medial face of the third tendon series. Muscle fibers of the second tendon series invade the iliosynsacral canal (Tsuihiji, 2005; Organ, 2006). The craniodorsal and caudodorsal edge of the neural spines can be slightly or strongly drawn out into a bony process, to which the tendons of the first and second series attach. The third and lateralmost tendon series originates at the craniodorsal edge of the neural spines dorsal to the first tendon series and proceeds cranioventrally. Muscle fibers emanate mainly from the medial side of this tendon series and insert at the dorsal half of the neural spines, at the postzygapophyses, medially at the transverse processes, and at the second tendon series. The caudalmost tendon of the third tendon series originates from the cranial margin of the ilium (Tsuihiji, 2005). In some avians, a fourth series of aponeuroses of $\mathrm{m}$. longus colli dorsalis pars thoracica is present, inserting between the other series at the caudal surface of the postzygapophyses and being in close contact with muscle fibers of $\mathrm{m}$. longus colli dorsalis, pars thoracica, $\mathrm{m}$. ascendentes thoracicus, and $\mathrm{m}$. longus colli dorsalis, pars caudalis (Fisher and Goodman, 1955; Zusi and Bentz, 1984; Tsuihiji, 2005).

The transverse processes in the trunk of avians are divided into a smooth medial part and a rugose, slightly or strongly beveled lateralmost part, which is about one-fifth of the entire width of the transverse process. M. ascendentes thoracicus attaches to the lateral half or one-third of the smooth, medial part of the transverse processes, lateral to $\mathrm{m}$. longus colli dorsalis pars thoracica (Fig. 1F) (Tsuihiji, 2005). The serial m. ascendentes thoracicus consists of short muscle slips that attach with tendinous and fleshy parts at the cranial and dorsal surface of the transverse processes, and in some taxa also on a calcified tendon of m. iliocostalis (Fisher and Goodman, 1955; Organ, 2006). The individual muscle slips extend from each transverse process for at least one or two vertebra cranially and insert at the caudolateral surface and the prominent torus dorsalis of the postzygapophyses, as well as on the caudal face of the transverse processes. A bony spur is sometimes caudally drawn out from the torus dorsalis and serves as insertion area for muscle slips of $m$. ascendens thoracicus. Furthermore, the cranial and caudal margin of the transverse processes of avians is often drawn out into short or long rod-like processes, which mark the insertion of muscle slips of $\mathrm{m}$. ascendentes thoracicus. The insertion of this muscle at the postzygapophyses can also be by aponeuroses, which also serve as attachment area for muscle fibers 
A

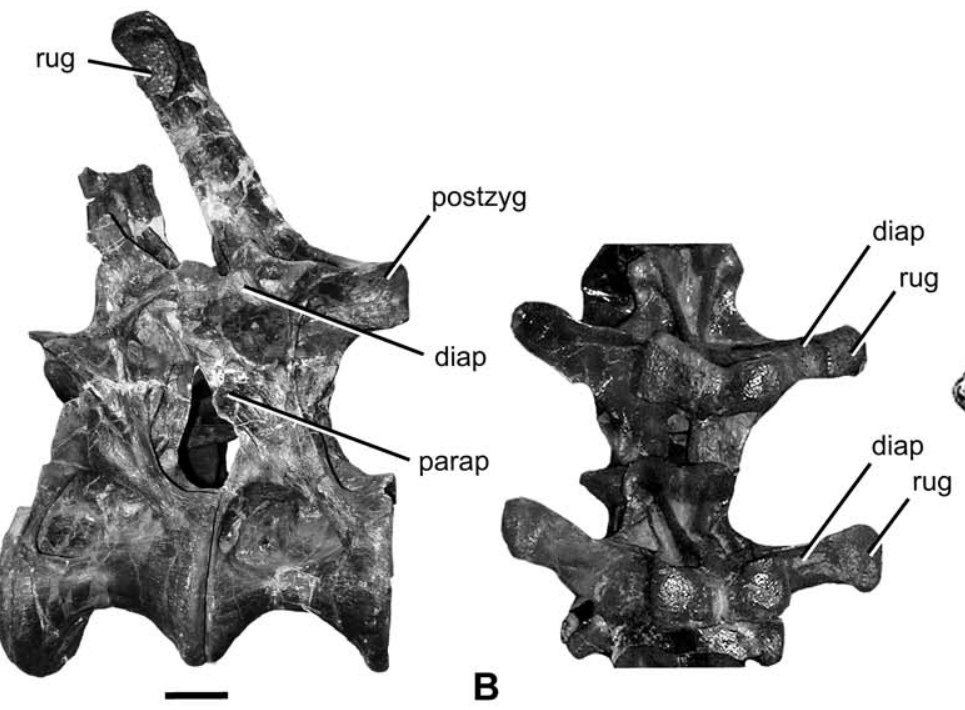

c

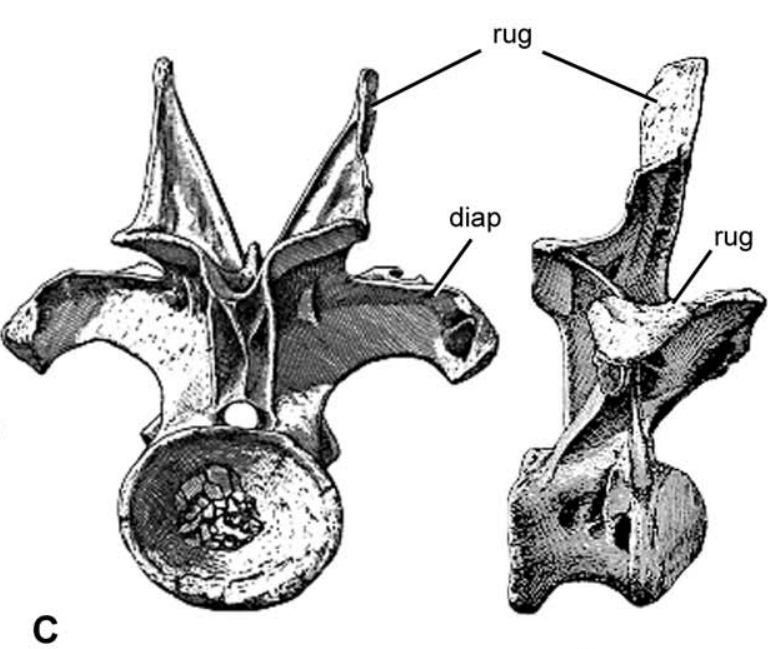

mitrasp nos
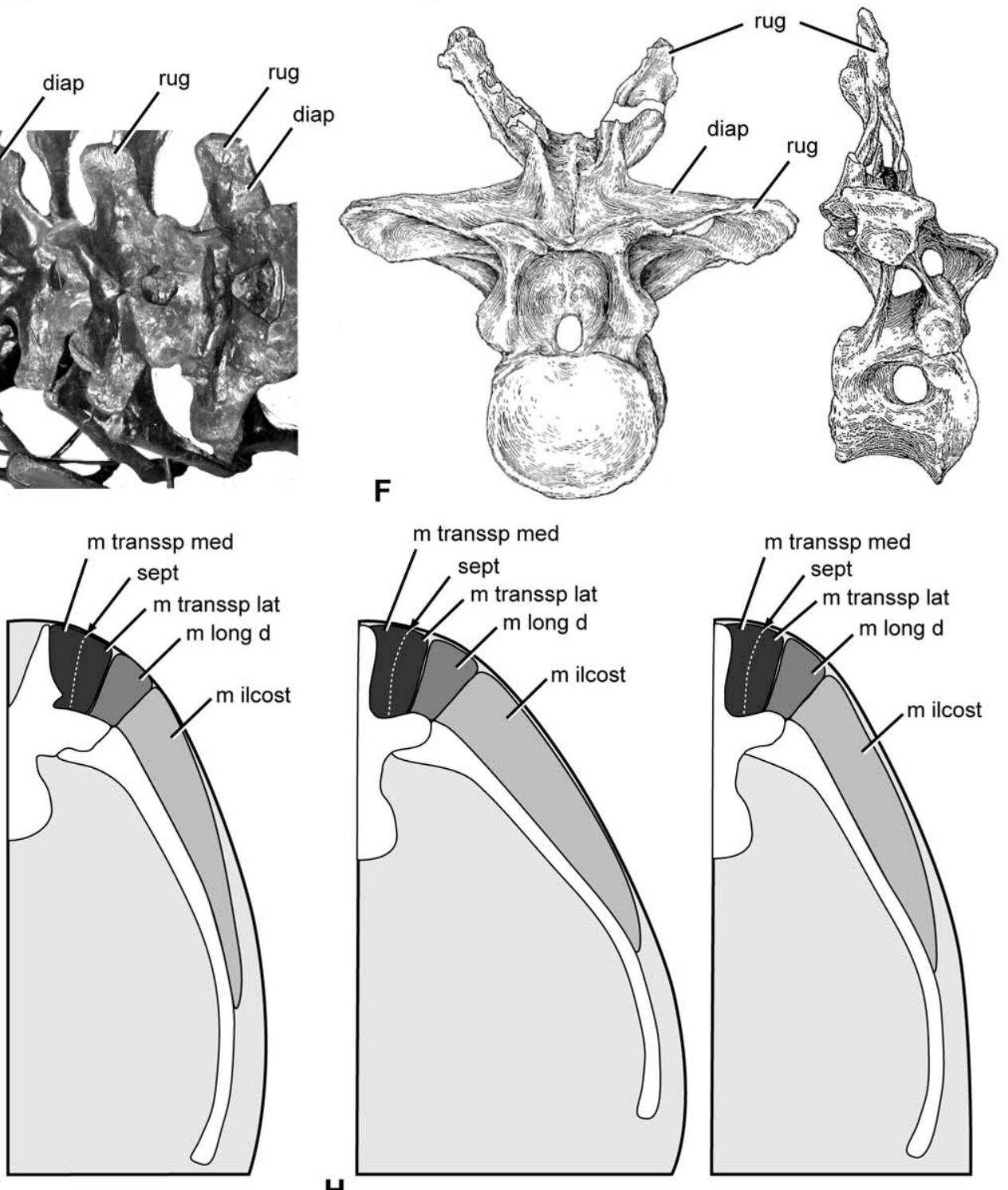
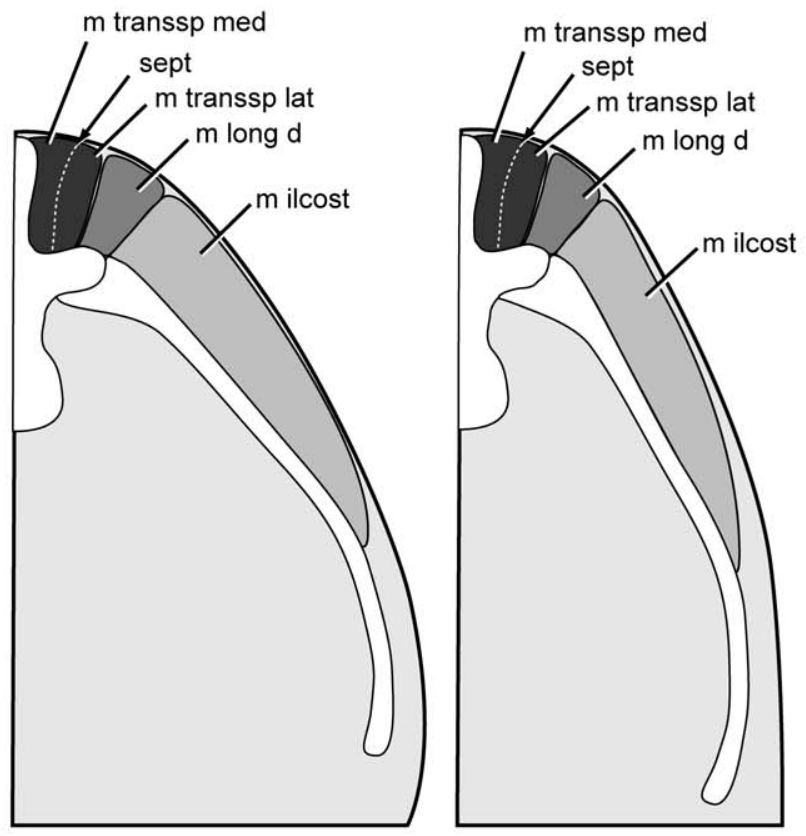

D

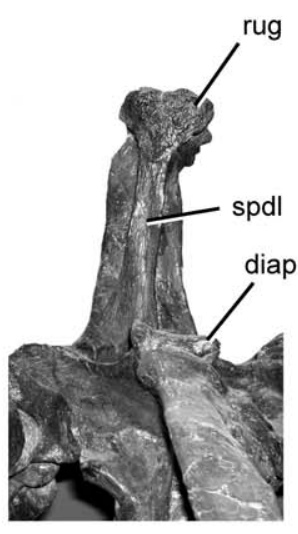

E

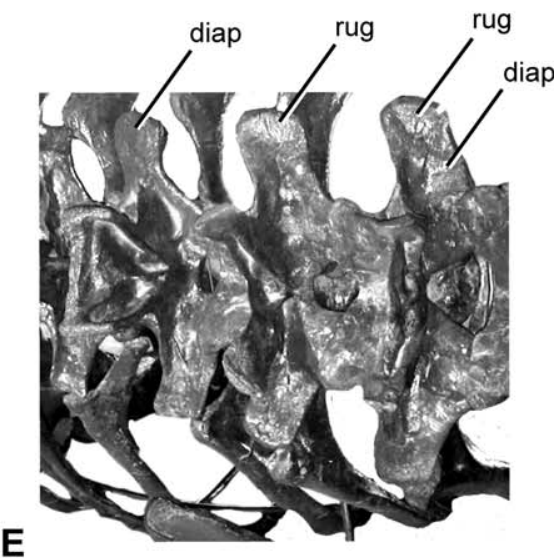

G

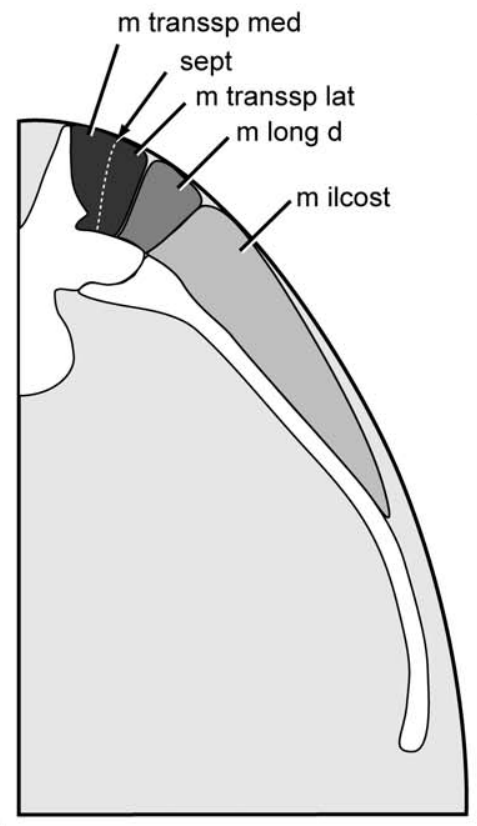

H 
TABLE 2. Origin and insertion of thoracic epaxial muscles in Crocodylia and Aves, and as reconstructed for sauropods with Levels of inference indicated in brackets.

\begin{tabular}{llll}
\hline Muscle or Muscle Group & \multicolumn{1}{c}{$\begin{array}{c}\text { Origin (OR) and Insertion (IN) } \\
\text { in Crocodylia }\end{array}$} & $\begin{array}{c}\text { Origin (OR) and Insertion (IN) } \\
\text { in Aves }\end{array}$ & $\begin{array}{c}\text { Origin (OR) and Insertion (IN) } \\
\text { in Sauropods }\end{array}$ \\
\hline $\begin{array}{l}\text { deep layer of } \\
\text { m. transversospinalis } \\
\text { group }\end{array}$ & $\begin{array}{l}\text { OR: mm. isp: cranial edges of } \\
\text { neural spines; mm. iart: base of } \\
\text { neural spine, cranial face of } \\
\text { postzygapophyses, prezygapophyses }\end{array}$ & $\begin{array}{l}\text { OR: mm. isp: cranial edges of } \\
\text { neural spines: mm. icr: base of } \\
\text { neural spine, cranial face of } \\
\text { postzygapophyses }\end{array}$ & $\begin{array}{l}\text { OR: base of neural spine, cranial face of } \\
\text { postzygapophyses [I'], cranial edges of } \\
\text { neural spines [I'] }\end{array}$
\end{tabular}

IN: mm. isp: caudal edges of neural IN: mm. isp: caudal edges of neural spines; mm. iart: caudal face of postzygapophyses

m. transversospinalis, medial part

OR: m. mult: tendinous on caudodorsal corner of neural spine; $\mathrm{m}$. spin: tendinous on craniodorsal corner of neural spine; $m$. artspin: aponeurotically from ligamentum cingulatum and medialmost paravertebral osteoderm, caudodorsal corner of neural spines, myosept of $\mathrm{m}$. tendinoarticularis IN: m. mult: fleshy on lateral face of neural spine, roof of neural arch, articular capsule of zygapophyses; $\mathrm{m}$. spin: fleshy on $\mathrm{m}$. mult and its tendon and caudal faces of postzygapophyses; $\mathrm{m}$. artspin: fleshy on $\mathrm{m}$. spinalis tendons, roof of neural arch, articular capsules of zygapophyses

m. transversospinalis, lateral part

OR: by myosepta at ligamentum cingulatum, medial and lateral paravertebral osteoderm IN: by muscle fibres at roof of neural arch, dorsal face of medial third of transverse processes, caudal aspect of postzygapophyses

m. longissimus dorsi

OR: by myosepta from ligamentum cingulatum, internal face of lateral paravertebral osteoderm and caudal edge of transverse processes

IN: fleshy on striated dorsal face of transverse processes, fleshy and by myosepts at septum transversum, septum intermusculare dorsi OR: aponeurotically from craniodorsal iliac process, by myosepts from lateral margins of lateralmost paravertebral osteoderms

IN: fleshy at fascia lumbodorsalis, by myosepts laterally on thoracic ribs and septum transversum spines; $\mathrm{mm}$. icr: caudal face of postzygapophyses

OR: dorsally from lateral surface of iliac blade and cranial iliac margin;

$1^{\text {st }}$ tendon series: craniodorsal corner of neural spines; $2^{\text {nd }}$ tendon series: caudodorsal corner of neural spines; $3^{\text {rd }}$ tendon series:

craniodorsal corner of neural spine

IN: $1^{\text {st }}$ tendon series: caudally on postzygapophyses, roof of neural arch, laterally on neural spines and $2^{\text {nd }}$ tendon series; $2^{\text {nd }}$ tendon series: dorsally on postzygapophyses, $3^{\text {rd }}$ tendon series, iliosynsacral canal; $3^{\text {rd }}$ tendon series: dorsal half of neural spines, postzygapophyses, dorsomedially on transverse processes, cranial margin of ilium OR: tendinous and fleshy from cranial and smooth dorsal surface of transverse processes

IN: fleshy and aponeurotically at caudolateral surface and torus

dorsalis of postzygapophyses, caudal margin and dorsal face of transverse processes, caudal aspect of postzygapophyses

OR: as sometimes calcified tendon

from $\mathrm{m}$. ascendentes thoracicus,

fleshy from caudalmost transverse processes

IN: fleshy and tendinous at bevelled and rugose lateral part of transverse processes, caudolateral edge of transverse processes OR: aponeurotically from craniolateral margin of ilium, fleshy and tendinous from cranioventral edge of iliac blade

IN: fleshy and by muscle slips on heads and lateral surface of dorsal ribs
IN: caudal face of postzygapophyses [I'], caudal edges of neural spines [I']

OR: tendinous on craniodorsal corner of neural spine $[\mathrm{I}]$, tendinous on caudodorsal corner of neural spine [I]

IN: fleshy on lateral faces of neural spines and adjacent tendons [I'], roof of neural arches between zygapophyses and neural spines [I'], zygapophyseal capsule [I'], rugose postzygapophyseal part of spinopostzygapophyseal lamina [I']

OR: from cranial margins and dorsal surface of transverse processes [II], possibly by fascicles

IN: dorsal face of transverse processes [I'], caudal margins of transverse processes and PODL [II'], possibly by muscle fibres

OR: from lateralmost part of transverse processes [I], possibly by tendons

IN: on bounding septum to $\mathrm{m}$. transversospinalis [ $\left.\mathrm{I}^{\prime}\right]$, on lateralmost rough part of transverse processes [I], possibly tendinous and fleshy OR: aponeurotically from preacetabular process of ilium [I], fleshy from medial surface of preacetabular process [II']

IN: at lateral surface of dorsal ribs [I], possibly tendinous on caudolateral margin of dorsal ribs [II']

Abbreviations: m. artspin, m. articulospinalis; mm. iart, mm. interarticulares, mm. icr, mm. intercristales; mm. isp, mm interspinales; m. mult, m. multifidus; m. spin, m. spinalis; PODL, postzygodiapophyseal lamina.

of m. longus colli dorsalis, pars thoracica (Tsuihiji, 2005). M. ascendentes thoracicus are bounded from laterally by aponeurosis transversa, which extends from the cervical region into the trunk and inserts laterally on the rugose lateral edge of the transverse processes (Tsuihiji, 2005).
Diplodocidae and Dicraeosauridae- $M$. transversospinalis of diplodocid and dicraeosaurid sauropods most likely occupied the area between at least the medial half of the transverse processes, the zygapophyseal capsules, and the lateral surface of the neural spines of the trunk, as in extant Crocodylia and Aves (Figs. 2, 3;

FIGURE 3. Thoracic epaxial musculature in Diplodocidae. A-F, dorsal vertebrae and osteological correlates for thoracic epaxial musculature. A, dorsals 6-7 of Diplodocus carnegii (CM 94) in left lateral view; B, dorsals 7-8 of Diplodocus carnegii (CM 84, mounted skeleton) in dorsal view; C, dorsal 3 of same, from Hatcher (1901: pl. 7) in caudal (left) and right lateral (right) views; D, neural spine of dorsal 8 of Apatosaurus louisae (CM 3018) in left lateral view; E, dorsals 3-5 of same in dorsal view; F, dorsal 4 of Apatosaurus ajax (NSMT-PV 20375) in cranial (left) and right lateral (right) views, from Upchurch et al. (2004b: Pl. 3). Scale bar equals $10 \mathrm{~cm}$. G-H, cross-sections of the diplodocid trunk with reconstructed thoracic epaxial muscles. The cross-sections depict ventrolaterally inclined (left) and caudoventrally inclined (right) dorsal ribs. Different inclinations of the dorsal ribs affect vertical orientation of $\mathrm{m}$. iliocostalis and its distance to the vertebrae. G, Diplodocus, cross-section at a cranial dorsal vertebra with bifurcate neural spine; $\mathbf{H}$, Apatosaurus, cross-section at a mid-dorsal vertebra with single neural spine. Not to scale. Abbreviations: diap, diapophysis; m ilcost, $\mathrm{m}$. iliocostalis; $\mathbf{m}$ long $\mathbf{d}$, $\mathrm{m}$. longissimus dorsi; $\mathbf{m}$ transsp lat, lateral part of $\mathrm{m}$. transversospinalis; $\mathbf{m}$ transsp med, medial part of m. transversospinalis; parap, parapophysis; rug, rugosity; sept, bounding septum; spdl, spinodiapophyseal lamina. 
Table 2). There is no osteological trace for the attachment of a distinct septum along the zygapophyseal capsules, separating the medial and lateral part of $\mathrm{m}$. transversospinalis from each other. Because in both extant Crocodylia and in extant Aves the medial part of $\mathrm{m}$. transversospinalis is clearly separated from its lateral part, a similar division by a bounding septum is likely in Diplodocidae and Dicraeosauridae (Level I' inference).

The lateral face of the dorsal neural spines of dicraeosaurids and diplodocids bears a distinct dorsal rugosity that forms the dorsal continuation of the spinodiapophyseal and spinopostzygapophyseal lamina. A similar rugosity is present on the neural spines of the dorsal vertebrae of extant Crocodylia, representing the attachment sites of two tendon systems of $\mathrm{m}$. transversospinalis (see above). Two opposite-directed tendon series of $\mathrm{m}$. transversospinalis are homologous in both Crocodylia and Aves: $\mathrm{m}$. spinalis/m.longus colli dorsalis, medial part and $\mathrm{m}$. articulospinalis $/ \mathrm{m}$. longus colli dorsalis, lateral part (Tsuihiji, 2005; Organ, 2006). The rugosity on the tip of the neural spines of Diplodocidae and Dicraeosauridae can be recognized as the osteological correlate of these two tendon series. Therefore, based on the conditions in Crocodylia and Aves, it can reconstructed as a Level I inference that $\mathrm{m}$. transversospinalis, pars medialis of sauropods comprised at least these two tendon systems originating from the rugosity on the dorsal part of the neural spines (Fig. 4A). Specifically, there was probably one series of tendons with associated muscle fibers or series of muscle slips ( $\mathrm{m}$. spinalis) extending from the craniolateral face of the neural spine cranioventrally, and a second series of tendons with associated muscle fibers ( $\mathrm{m}$. articulospinalis) extending from the caudolateral face of the neural spine caudoventrally. These series of muscle slips would have been oriented in opposite directions to each other and inserted with muscle fibers at the lateral face of the neural spines, the roof of the neural arches between the zygapophyseal capsules and the neural spines, and the rugose postzygapophyseal part of the spinopostzygapophyseal lamina (Table 2). The lengths of the tendons cannot be reconstructed by osteological evidence. Because the length of these tendons both in extant Crocodylia and Aves usually varies between four and five vertebral segments, a similar range is also likely for the homologous tendons in Diplodocidae and Dicraeosauridae.
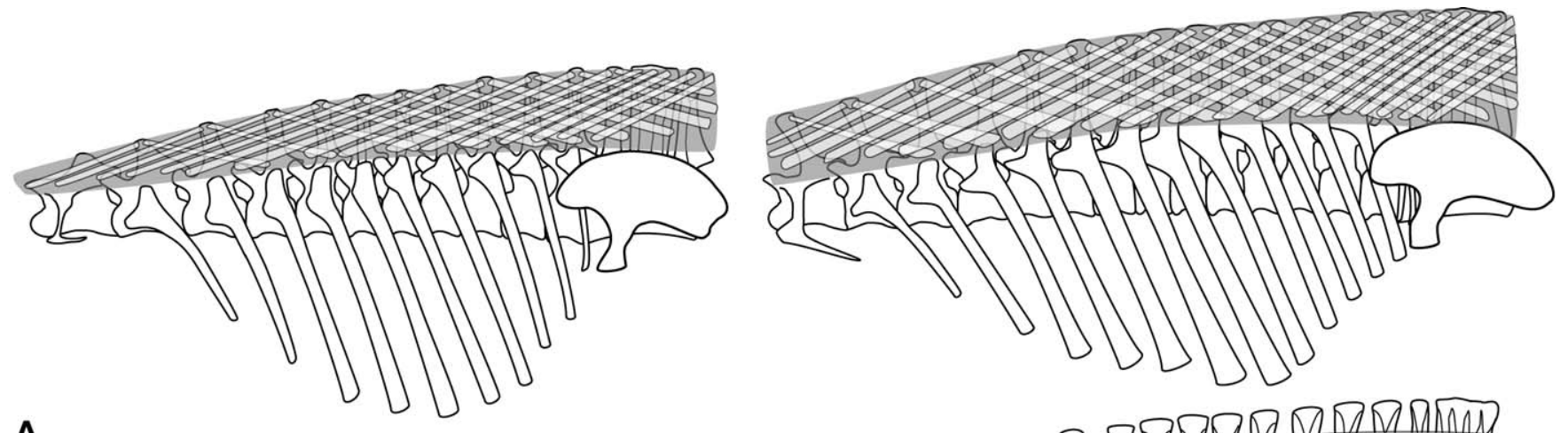

A

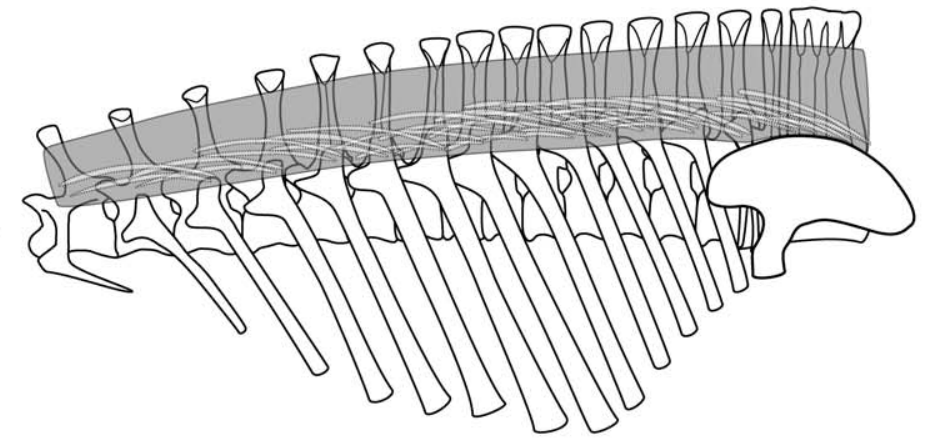

B
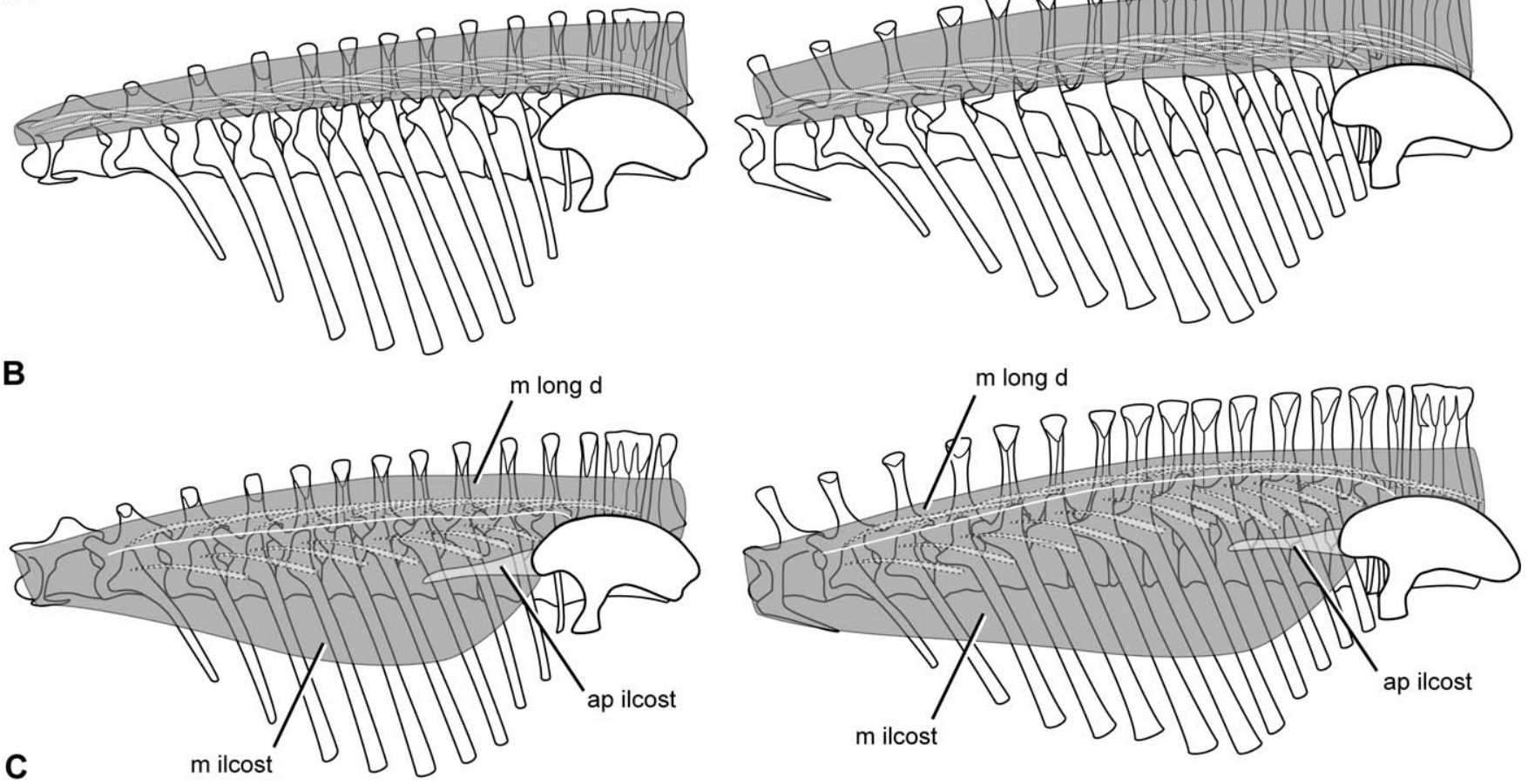

FIGURE 4. Reconstructions of tendon arrangement in thoracic epaxial muscles in Diplodocus (left) and Dicraeosaurus (right), in left lateral view. A, medial part of $\mathrm{m}$. transversospinalis: first tendon-system homologous to $\mathrm{m}$. spinalis extends from the craniolateral face of the neural spine cranioventrally, second tendon-system homologous to $\mathrm{m}$. articulospinalis extends from the caudolateral face of the neural spine caudoventrally; $\mathbf{B}$, lateral part of $\mathrm{m}$. transversospinalis. The arrangement of the tendons cannot be reconstructed by osteological evidence; $\mathbf{C}, \mathrm{m}$. longissimus dorsi and $\mathrm{m}$. iliocostalis. Only the aponeurosis of $\mathrm{m}$. iliocostalis is reconstructed by osteological evidence. Not to scale. Abbreviations: ap ilcost, large attachment aponeurosis of $\mathbf{m}$. iliocostalis to preacetabular process of ilium; $\mathbf{m}$ ilcost, $\mathrm{m}$. iliocostalis; $\mathbf{m}$ long $\mathbf{d}$, $\mathrm{m}$. longissimus dorsi. 
However, the differences in the neural spine heights in the trunk of diplodocid sauropods and Amargasaurus were most likely compensated by slightly varying tendon lengths to maintain similar insertion angles of the two medial tendon series at the neural spines throughout the dorsal vertebral column. In contrast, the similar heights of the neural spines of Dicraeosaurus suggest relatively similar tendon lengths of the tendon series throughout the dorsal vertebral column (Fig. 4A).

The direction and morphology of the neural spines of sauropods gives no hint as to whether there was a medialmost tendon series proceeding caudally like in m. multifidus in crocodylians. An avian-like ossified medial tendon series of m. transversospinalis has been reconstructed for many ornithopod dinosaurs (Norman, 1980; Organ, 2006). This might suggest evolution of this arrangement at the base of the dinosaurian evolutionary tree (Organ, 2006), with m. multifidus being absent, in which case a bird-like arrangement of these tendons in sauropodomorphs in general could be assumed. In contrast, the ossified tendons of the ankylosaur Minmi show a crocodylian-like arrangement (Molnar and Frey, 1987; Organ, 2006), which might indicate a larger variability of tendon-arrangements of $\mathrm{m}$. transversospinalis within Dinosauria, or merely non-ossification of the medialmost $\mathrm{m}$. multifidus in most ornithischians. It therefore cannot be excluded that the avian arrangement of the medial tendon series of $\mathrm{m}$. transversospinalis without $\mathrm{m}$. multifidus has instead evolved within more basal Theropoda; in which case it is more likely that diplodocid and dicraeosaurid sauropods possessed m. multifidus.

There are also no unambiguous osteological correlates for a robust (Level I) inference of an additional, more laterally positioned series of tendons belonging to the medial part of $\mathrm{m}$. transversospinalis and extending from the dorsal neural spines in cranial direction. Therefore, the presence or absence of such a laterally positioned series of tendons in Diplodocidae and Dicraeosauridae cannot be reconstructed reliably by the applied EPB approach. At least for Dicraeosauridae, the small transverse width available for insertion of $\mathrm{m}$. transversospinalis pars medialis on the transverse processes makes it unlikely, that the muscle was laterally supplemented by another series of tendons.

It is likely that $\mathrm{m}$. transversospinalis of diplodocid and dicraeosaurid sauropods contained tendons/aponeuroses or fascicles as in extant Crocodylia and Aves (Fig. 4B). If an avian-like division and arrangement of this muscle is assumed for sauropods, then the lateral part of $\mathrm{m}$. transversospinalis could have been arranged in cranially proceeding fascicles (Level II'). In this case, the tendons would have originated from the cranial margins of the transverse processes and proceeded cranially over some segments (Fig. 4). The fascicles would have likely inserted by muscle fibers at the dorsal surface and caudal margins of the transverse processes, and the rugose postzygodiapophyseal lamina (Table 2). The presence of a rough lateral area at the transverse processes indicates the presence of a bounding septum lateral to $\mathrm{m}$. transversospinalis similar to septum intermusculare dorsi in Crocodylia and aponeurosis transversa in Aves (Level I inference). Diplodocidae and Dicraeosauridae possessed pneumatic structures in the presacral vertebral column (Wedel, 2003; Schwarz et al., 2007), and the lateral surface and base of the neural spines is often restricted to thin laminae with pneumatic fossae and foramina in between. Reconstructing a tendinous or fascicular arrangement of $\mathrm{m}$. transversospinalis would mean that these tendons inserted mainly on small areas (such as defined crests or laminae) of the bone, which would have allowed an intermingling of the muscle fibers by pneumatic diverticula.

\section{M. longissimus dorsi}

Crocodylia-M. longissimus dorsi of extant Crocodylia occupies the lateral two-thirds of the width of the transverse process- es (Fig. 1E) (Frey, 1988a; Salisbury, 2001). M. longissimus dorsi is made up of myosepta that form a series of large cones tapering from craniodorsally to caudoventrally (Fig. 1B). The ventrally open myoseptal cones allow bundles of longer muscle fibers to pass longitudinally through them. The myosepta in the cranialmost dorsal vertebrae originate at the internal surface of fascia lumbodorsalis, and caudal to those at ligamentum cingulatum, the internal face of the lateral paravertebral osteoderm, and at the caudal edge of the transverse process. The fleshy part of $\mathrm{m}$. longissimus dorsi inserts at the dorsal face of the transverse processes. Fleshy parts and myosepta insert also at the caudal edge at the laterally bounding septum transversum and the medially bounding septum intermusculare dorsi (Frey, 1988a; Murakami et al., 1991). At the dorsal surface of the transverse processes, the insertion area of $\mathrm{m}$. longissimus dorsi is rugose with transversely oriented striations (Table 2).

Aves-The avian m. iliocostalis is organized into a complex system of tendons and muscle slips that extend over the lateralmost part of the transverse processes and the dorsalmost part of the dorsal ribs between the ilium and the first dorsal rib. The craniodorsal part of $\mathrm{m}$. iliocostalis of avians, considered homologous to $\mathrm{m}$. longissimus dorsi of Crocodylia (Table 1), originates superficially as a tendon (sometimes calcified) from $\mathrm{m}$. ascendentes thoracicus together with the caudoventral part of $\mathrm{m}$. iliocostalis (Fig. 1D). Its fleshy part also originates from the caudalmost transverse processes of the dorsal vertebrae (Fisher and Goodman, 1955; Zusi and Bentz, 1984; Organ, 2006). The craniodorsal part of $\mathrm{m}$. iliocostalis inserts with tendons and muscle fibers on the slightly beveled lateral part of the surface of the transverse processes. In avians, the lateralmost part of the transverse processes bears longitudinal crests or forms a prominent rugose edge and can be drawn out caudally into long and thin spines for the insertion of the long tendons of the craniodorsal part of $\mathrm{m}$. iliocostalis. Muscle fibers of the craniodorsal part of $\mathrm{m}$. iliocostalis contact medially aponeurosis transversa and interweave with fibers of $\mathrm{m}$. ascendentes thoracicus (Tsuihiji, 2005).

Diplodocidae and Dicraeosauridae-The roughened lateral part of the transverse processes of these sauropods, which characterizes the insertion area of $\mathrm{m}$. longissimus dorsi in extant Crocodylia and Aves (see above), is the attachment of $\mathrm{m}$. longissimus dorsi (Level I inference). Taking the osteological correlates of this roughened area and the mostly small lateral extension of the transverse processes as reference, $\mathrm{m}$. longissimus dorsi of Diplodocidae and Dicraeosauridae is reconstructed to have attached only on the lateral part of the transverse processes and to have had a relatively small cross-section (Figs. 2E, F; 3G, H).

Both extant Aves and Crocodylia have an internal tendinous organization of $\mathrm{m}$. longissimus dorsi, making a similar tendinous division in sauropods likely (Level I' inference). However, osteological correlates such as distinct longitudinal crests, which would be evidence for a strong tendinous system of $\mathrm{m}$. longissimus dorsi as in avians, are lacking in sauropods. The organization into broad myosepta as in extant crocodylians is also unlikely, because a shield of paravertebral osteoderms is lacking in sauropods. Comparing the insertion points of the tendons and myosepta in Crocodylia and Aves, tendons or fascicles as well as fleshy fibers of $\mathrm{m}$. longissimus dorsi of sauropods might have originated from the lateralmost aspect of the transverse processes (Table 2) and from there extended caudally to insert on the septum separating $\mathrm{m}$. longissimus dorsi from the medially-lying $\mathrm{m}$. transversospinalis (septum intermusculare dorsi) and on the caudally adjacent transverse processes (Fig. 4). If m. longissimus dorsi was restricted to the lateralmost part of the transverse processes and a complete septum intermusculare dorsi was present in Diplodocidae and Dicraeosauridae, then an insertion of fibers of this muscle on the lateral part of the prezygapophyses like in Crocodylia would be unlikely. 
Diplodocidae and Dicraeosauridae share with extant Aves the position of the caudalmost one or two dorsal ribs medial to the ilium (Upchurch et al., 2004a) and the lateromedial division of the transverse processes (see above). Together with the proposed small extension of the muscle hypothesized above, this suggests an avian-like close connection between $\mathrm{m}$. longissimus dorsi and $\mathrm{m}$. iliocostalis, although this cannot be proven by osteological evidence (Figs. 2, 3).

\section{M. iliocostalis}

Crocodylia-M. iliocostalis extends from the cranial process of the ilium along the dorsal ribs and continues in the neck as m. iliocostalis cervicis (Frey, 1988a). M. iliocostalis covers the lateral surface of the dorsal ribs and is externally bounded by fascia lumbodorsalis. The muscle is subdivided into simple, wall-like myosepta that insert caudolaterally along the long axis of the dorsal ribs (Fig. 1A). At their mediodorsal edge, the myosepta contact septum transversum and ligamentum cingulatum, thus making a connection to the paravertebral osteodermal shield (Emelianov, 1936; Frey, 1988a, b; Salisbury, 2001). Cartilaginous uncinate processes emerge from the dorsal ribs and are embedded into these myosepta (Frey, 1988a). The caudalmost three to five presacral ("lumbar") vertebrae of Crocodylia lack dorsal ribs (Hoffstetter and Gasc, 1969). In this region, $\mathrm{m}$. ilicostalis tapers and divides into a dorsal and a ventral part (Fig. 1B). At its caudal end, $\mathrm{m}$. iliocostalis forms a strong aponeurosis, which inserts at the strongly rugose craniodorsal tubercle of the ilium (Bornhauser and Ziswiler, 1983; Frey, 1988a).

Aves-The caudoventral part of m. iliocostalis (Table 1) originates as aponeurosis from the craniolateral margin of the ilium (Fig. 1D), and as fleshy and tendinous parts from the cranioventral edge of the iliac blade (Fisher and Goodman, 1955; Zusi and Bentz, 1984; Organ, 2006). The muscle is organized into muscle slips, which insert on the proximal part of the shafts of the dorsal ribs (Zusi and Bentz, 1984; Tsuihiji, 2005). In the synsacrum, the caudoventral part of $\mathrm{m}$. iliocostalis inserts on the dorsal ribs medially to the ilium. The distinct, caudodorsally directed uncinate processes at the medial dorsal ribs have no contact with m. iliocostalis.

Diplodocidae and Dicraeosauridae - The ilium of diplodocid and dicraeosaurid sauropods has a large preacetabular process with a broadened and slightly roughened cranial margin. The preacetabular iliac process is deflected craniolaterally. The origination of $\mathrm{m}$. iliocostalis from the preacetabular region both in Crocodylia and Aves makes it probable that this region was also the area of origin of m. iliocostalis in Diplodocidae and Dicraeosauridae (Level I inference). Additionally, due to the avian-like position of the caudalmost dorsal ribs medial to the ilium in diplodocids and dicraeosaurids, it is likely that $\mathrm{m}$. iliocostalis in sauropods originated similarly from medial surface of the preacetabular iliac process (Level II' inference). The strong cranial rugosity of the preacetabular process suggests an aponeurotic origin of $\mathrm{m}$. iliocostalis (Fig. 4C).

M. iliocostalis most likely inserted on the dorsal ribs, including those positioned medially to the preacetabular process (Table 2, Level I inference). According to the reconstructed position and dimensions of $\mathrm{m}$. iliocostalis of Diplodocidae and Dicraeosauridae, muscle fibers possibly attached on the aponeurosis of $\mathrm{m}$. iliocostalis, the surfaces of the ribs, the bounding septa or fascia, and the cranial process of the ilium. The size and position of the preacetabular process of the ilium make it likely that $\mathrm{m}$. iliocostalis covered at least the dorsal half of the rib lengths (Figs. 2-4). The laterally deflected and large preacetabular process of the ilium of Diplodocidae and Dicraeosauridae together with the long dorsal ribs possibly points towards a large cross-section of $\mathrm{m}$. iliocostalis, which likely was positioned laterally and ventrally to the vertebral column (Figs. 2-4). However, the cross-section of $\mathrm{m}$. iliocostalis would be lateromedially more narrow in case that the dorsal ribs would be straight laterally inclining (compare different reconstruction variations in Figs. 2 and 3). In Amargasaurus, the extreme height of the dorsal neural spines leads to an increase of the height (and therefore also the cross-section) of all epaxial muscles, which becomes particularly visible in $\mathrm{m}$. iliocostalis (Fig. 2F).

There is no osteological evidence for the internal organization of $\mathrm{m}$. iliocostalis in sauropods. The avian-like reduction in the of dorsal vertebrae and consequent short trunk of diplodocid and dicraeosaurid sauropods and their vertically oriented dorsal ribs positioned partially medially to the ilium, suggests an more avian than crocodylian like arrangement of $m$. iliocostalis. If this were the case, $\mathrm{m}$. iliocostalis might have been organized into long tendons instead of myosepta (Fig. 4C). These tendons could have inserted on the caudolateral margin of the dorsal ribs (Table 2, Level II' inference). Furthermore, there is no osteological evidence for a bounding septum between $\mathrm{m}$. longissimus dorsi and $\mathrm{m}$. iliocostalis. It is uncertain if these two muscles were separated by a thin bounding septum similar to septum transversum of Crocodylia, or if their muscle fibers enlaced each other in the contact area as in Aves. Because m. longissimus dorsi of Diplodocidae and Dicraeosauridae continued caudally into the tail, whereas $\mathrm{m}$. iliocostalis caudally ended at the ilium, a separation between both muscles was likely present at least in the iliac region (Fig. 4C).

\section{DISCUSSION}

\section{Levels of Inference and Problems with Reconstructed Epaxial Muscles}

Except for the deep layer of $\mathrm{m}$. transversospinalis and a lateral tendon series of $\mathrm{m}$. transversospinalis, osteological correlates are present that allow the reconstruction of muscle fibers and or tendons of the different epaxial muscles with a Level I inference. The deep layer of $\mathrm{m}$. transversospinalis and a lateral tendon series of $\mathrm{m}$. transversospinalis are also present in both extant outgroups (Crocodylia and Aves), but because they show no unambiguous osteological correlates, can only be reconstructed with a Level I' inference.

In most cases, it is not possible to reconstruct details of origin and insertion as well as tendon arrangement for the epaxial muscles on the basis of osteological correlates, and inference levels range from Level I to Level II'. The presence of Level II and II' inferences reflects substantial differences in configuration of thoracic epaxial muscles and the support system of the trunk between both extant outgroups (see "Configuration and homology of thoracic epaxial musculature in extant Archosauria"). Diplodocid and dicraeosaurid sauropods appear similar to extant avians in the presence of a high-oval cross-section of the trunk, small lateral width of the transverse processes, dorsoventrally separated parapophyses and diapophyses, and presence of a rugose and often beveled lateral part of the transverse processes. Together with the lack of a dorsal shield of paravertebral osteoderms, this might also indicate more similarities in the configuration of the thoracic epaxial muscles between these sauropods and avians than with crocodylians. However, the peculiarities of the dorsal vertebrae of Diplodocidae and Dicraeosauridae make it likely that they might have looked neither like crocodylians nor like birds, but have developed their own muscular configuration. Thus, although the EPB approach provides a transparent and parsimonious method, it is obviously not sufficient to reconstruct all aspects of sauropod thoracic epaxial muscles. This is not only because sauropods differ from their extant outgroups both in their enormous size, and in features of their vertebral morphology, but also because of the fact 
that substantial differences exist between extant Crocodylia and Aves in the thoracic epaxial muscle morphology and overall trunk reconstruction. Especially complex configurations of the muscles, such as their tendon arrangement or overall extension, usually cannot be deduced directly from osteological traces and therefore will remain speculative.

\section{Implications for the Thoracic Epaxial Musculature of Eusauropods}

The dorsal vertebrae of other eusauropods are similar to those of Diplodocidae and Dicraeosauridae in having a small width of the transverse processes with a lateral rugosity, a laterally rugose dorsal end of the neural spines, and vertically oriented dorsal ribs in cranial view. These osteological characters suggest a similar distribution of the thoracic epaxial muscles in other eusauropods as in diplodocids and dicraeosaurids. Howev$\mathrm{er}$, there is much morphological variation in the dorsal vertebrae of different eusauropods concerning the height and morphology of the neural spines, the width of the transverse processes, and the presence or absence of laminae on the neural spines. This variation suggests also variation in the insertion angles and lengths of the tendons of the medial part of $\mathrm{m}$. transversospinalis, and in the cross-sections of the individual epaxial thoracic muscles. Below, some examples are given for non-diplodocoid eusauropods.
Non-neosauropod Eusauropods-Shunosaurus (Dong et al., 1983; Zhang et al., 1984; Peng et al., 2005) possesses dorsal neural spines that increase in height in the cranial half of the trunk to 2.6 times of the height of the vertebral body (Fig. 5A). The medial part of $\mathrm{m}$. transversospinalis can be reconstructed as dorsoventrally high, with tendons of different lengths to compensate the increase in the neural spine tallness (Fig. 5D). The plate-like neural spines with only a few laminae provide a large insertion area for the muscle fibers of the medial part of $\mathrm{m}$. transversospinalis. The transverse processes are dorsally inclined and as broad as the vertebral bodies, which indicates a small cross-sectional area for $\mathrm{m}$. transversospinalis and $\mathrm{m}$. longissimus dorsi (Fig. 5B).

Haplocanthosaurus (Hatcher, 1903; McIntosh and Williams, 1988) has moderately tall and uniformly high neural spines of 1.3 times the height of the vertebral body. The transverse processes are strongly dorsolaterally inclined, approximately 1.3 times as broad as the vertebral body, and bear a rugosity in their lateral fourth. M. transversospinalis is reconstructed to have been vertically low and transversely narrow, followed laterodorsally by a small $\mathrm{m}$. longissimus dorsi (Fig. 5C). The tendon angles of the medial series of $\mathrm{m}$. transversospinalis were due to the low neural spines more shallow than in Diplodocidae and Dicraeosauridae. The lateral face of the neural spines of Haplocanthosaurus bears a spinodiapophyseal and a spinopostzygapophyseal lamina, which unite in the dorsal half of the neural spine. The presence
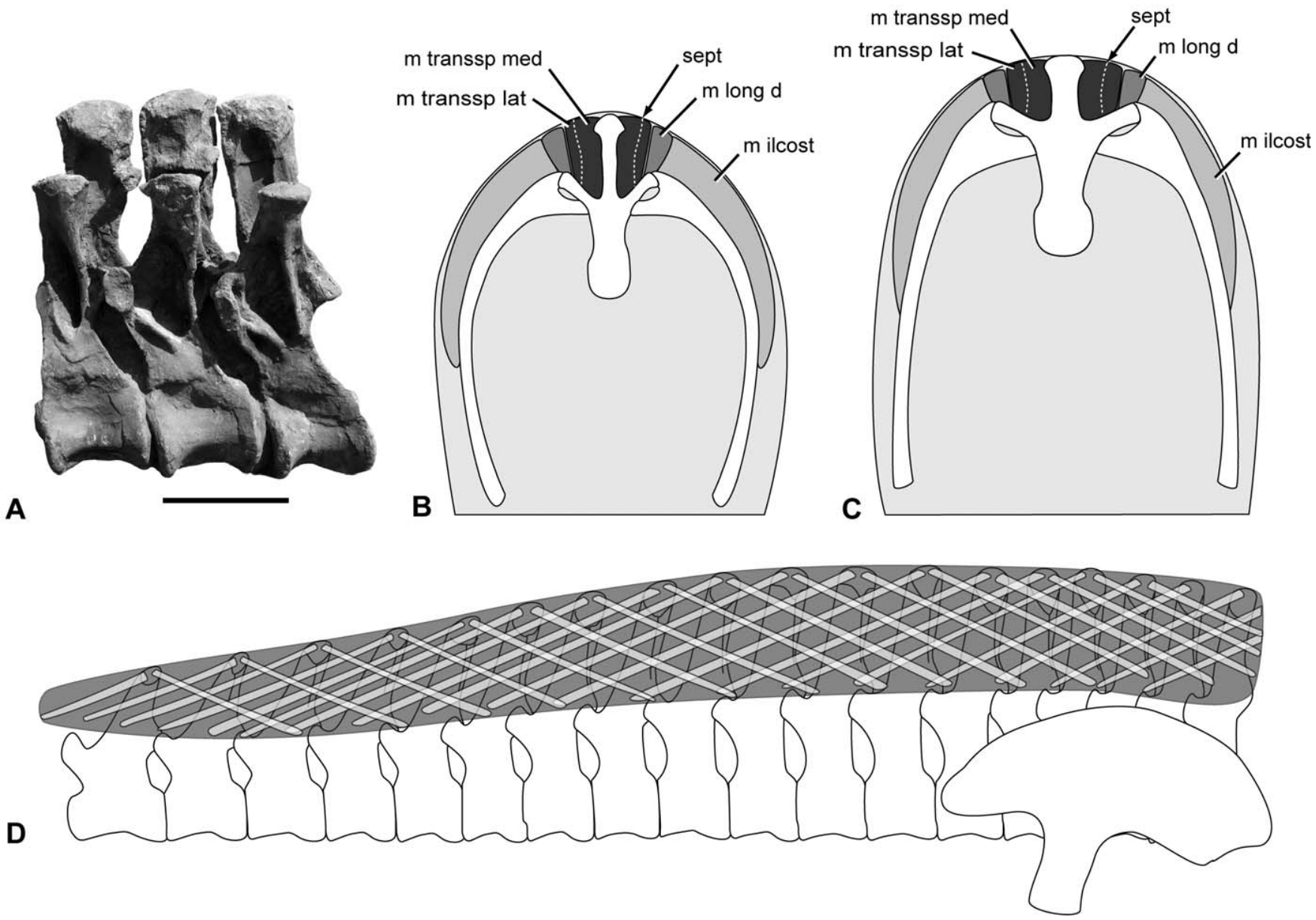

FIGURE 5. Reconstruction of thoracic epaxial musculature in some non-neosauropod eusauropods. A, three associated mid-dorsal vertebrae of Shunosaurus lii (IVPP, no collection number) in left lateral view, scale bar is $10 \mathrm{~cm}$; B, Shunosaurus, cross-section at a mid-dorsal vertebra; C, Haplocanthosaurus, cross-section at a mid-dorsal vertebra; D, Shunosaurus, medial part of $\mathrm{m}$. transversospinalis with reconstructed tendon girder in left lateral view. Not to scale. Abbreviations: $\mathbf{m}$ transsp lat, lateral part of $\mathbf{m}$. transversospinalis; $\mathbf{m}$ transsp med, medial part of $\mathbf{m}$. transversospinalis; m ilcost, $\mathrm{m}$. iliocostalis; m long d, m. longissimus dorsi; sept, bounding septum. 
of such a distinct lamina on the lateral face of the neural spines possibly indicates more tendons and less muscle fibers in the medial part of m. transversospinalis than in Shunosaurus.

Macronaria-Camarasaurus (e.g., Mook, 1914; Osborn and Mook, 1921; Gilmore, 1925; McIntosh et al., 1996b; McIntosh et al., 1996a; Ikejiri et al., 2005) has low neural spines in the cranial third of the trunk, which increase caudally to 1.3 times of the vertebral body height (Fig. 6). Like in other macronarians, the dorsal vertebrae of Camarasaurus bear a triangular lateral processes on the neural spines, which is ventrally con-

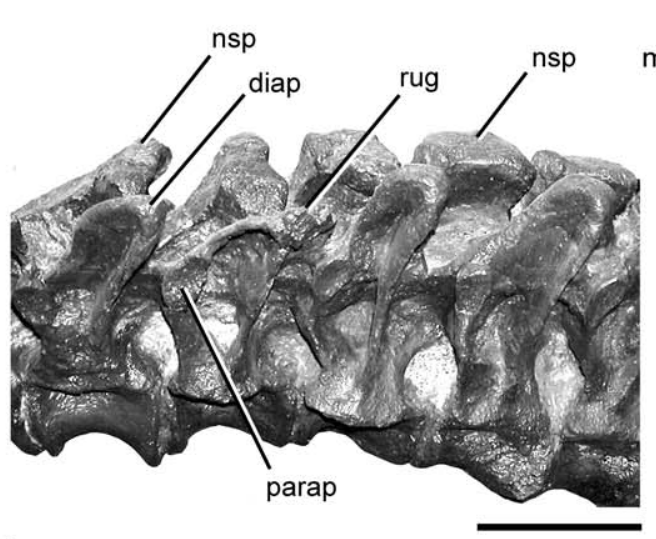

A
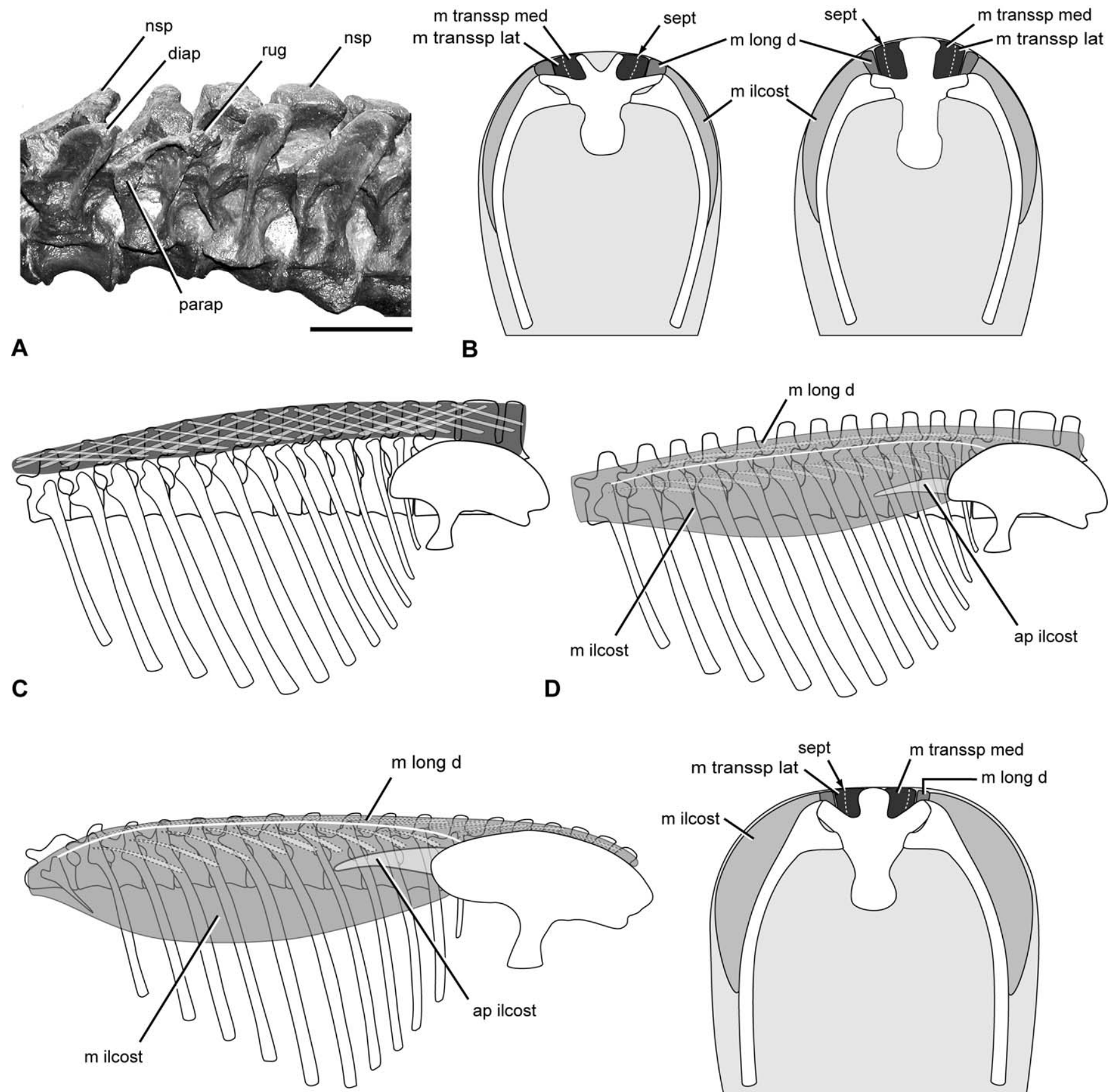

E

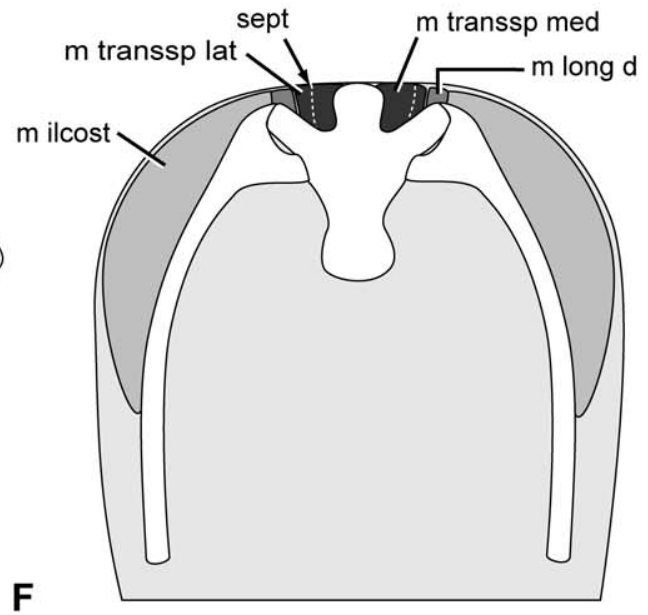

FIGURE 6. Reconstruction of thoracic epaxial musculature in macronarians. A-D, Camarasaurus lentus. A, mid-dorsal vertebrae of articulated skeleton CM 11338 in left lateral view, scale bar is $10 \mathrm{~cm}$; B, cross-sections in the cranial (left, bifurcate neural spine) and caudal (right, single neural spine) part of the trunk; $\mathbf{C}$, medial part of $\mathrm{m}$. transversospinalis: first tendon-system homologous to $\mathrm{m}$. spinalis extends from the craniolateral face of the neural spine cranioventrally, second tendon-system homologous to $\mathrm{m}$. articulospinalis extends from the caudolateral face of the neural spine caudoventrally; D, m. longissimus dorsi and $\mathrm{m}$. iliocostalis. Only the aponeurosis of m. iliocostalis is reconstructed by osteological evidence. E-F, Reconstructed thoracic epaxial musculature in Saltasaurus loricatus (osteology after Powell, 2003). E, m. longissimus dorsi and m. iliocostalis. Only the aponeurosis of $\mathrm{m}$. iliocostalis is reconstructed by osteological evidence; $\mathbf{F}$, cross-section of mid-dorsal vertebra. Not to scale. Abbreviations: diap, diapophysis; m ilcost, $m$. iliocostalis; m long d, m. longissimus dorsi; m transsp lat, lateral part of $\mathrm{m}$. transversospinalis; m transsp med, medial part of m. transversospinalis; nsp, neural spine; parap, parapophysis; rug, rugosity; sept, bounding septum. 
tinuous with the combined spinodiapophyseal and spinopostzygapophyseal lamina. This process is most equivalent to the distinct dorsal rugosity on the lateral face of the dorsal neural spines of dicraeosaurids and diplodocids, and represents the attachment site of the two medial tendon systems of $\mathrm{m}$. transversospinalis. The insertion angles of these tendons were probably shallow, and the tendons had relatively similar lengths (Fig. 6C, D). In the cranial half of the trunk, the transverse processes are 1.5 times as broad as the vertebral bodies and straight laterally directed, whereas they decrease in width and become slightly dorsally inclined in the caudal half of the trunk. There is a broad rugosity in the lateral third of the transverse processes. This combination suggests a vertically low and transversely broad cross-section of $\mathrm{m}$. transversospinalis that is in the cranial trunk about twice and in the caudal trunk about 1.5 times as broad as $\mathrm{m}$. longissimus dorsi (Fig. $6 \mathrm{~B})$. The cross-section of $\mathrm{m}$. transversospinalis decreased in caudal direction according to the inclination of the transverse processes.

Somphospondyli (e.g., Saltasaurus, Ampelosaurus, Alamosaurus, Rapetosaurus and Malawisaurus) have strongly caudally inclined dorsal neural spines. If the neural spines are considered as levers transmitting the forces of the epaxial muscles to the vertebral bodies, the direction of the neural spines would be determined by the resultant forces of the inserting muscles: the direction of the neural spines is usually perpendicular to the resultant sum of muscular forces acting on them (Slijper, 1946). The strong caudal inclination of the neural spines of Somphospondyli suggests independently from the individual neural spine heights that in contrast to other eusauropods the angles of opposite running tendons of the medial part of $\mathrm{m}$. transversospinalis were different: the cranially directed tendons most probably had steeper attachment angles than the caudally directed tendons.

Saltasaurids like Saltasaurus (Powell, 1992, 2003), Opisthocoelicaudia (Borsuk-Bialynicka, 1977), and Alamosaurus (Lehman and Coulson, 2002), possess very low (not more than 0.8 times of height of vertebral body) and inflated neural spines. This suggests that the series of tendons in the medial part of $\mathrm{m}$. transversospinalis had significantly lower insertion angles than in other eusauropods. The combination of low neural spines and narrow transverse processes might have led to a very narrow cross-sectional area for $\mathrm{m}$. transversospinalis (Fig. 6F), but would have allowed a dorsal extension of $\mathrm{m}$. iliocostalis until the level of the neural spine apices. The reduced laminae of the neural spines would have allowed the insertion of fleshy muscle fibers in the medial part of $\mathrm{m}$. transversospinalis directly onto the smooth lateral surface of the neural spines. It is therefore possible that the medial part of $\mathrm{m}$. transversospinalis of Saltasauridae contained more muscle fibers and less tendons than in other eusauropods, which might be reflected by a rather weak lateral rugosity of the neural spines. Additionally, the preacetabular process of the ilium of saltasaurids is strongly bent laterally with an angle of nearly $90^{\circ}$ to the long axis of the body (Wilson and Sereno, 1998; Upchurch et al., 2004a; Curry Rogers, 2005; Wilson, 2005). This enlarged preacetabular process might have facilitated enlargement of the cross-section of $\mathrm{m}$. longissimus dorsi and $\mathrm{m}$. iliocostalis (Fig. 6E, F). Interestingly, an analogy between the strongly laterally deflected preacetabular process of saltasaurid sauropods and the similarly laterally deflected cranial part of the ilium of large ungulates exists. In the latter, $\mathrm{m}$. iliocostalis and $\mathrm{m}$. longissimus dorsi are fused to form an $\mathrm{m}$. erector spinae, which extends by long fascicular muscle strands along the trunk, inserting at the laterally flared cranial iliac flange (Slijper, 1946). A similar suggestion for arrangement of lateral thoracic epaxial muscles in South American titanosaurs was made by Powell (2003) on the basis of comparisons with extant mammals.

\section{Functional Implications}

Following these reconstructions, a detailed biomechanical analysis of the sauropod trunk muscles together with a reconstruction of abdominal and ventral trunk muscles and of the trunk mobility would allow many functional conclusions concerning the stabilization of the vertebral column and locomotor capabilities. Limited functional implications can be given from the reconstructions of the epaxial thoracic muscles alone. Reconstructing the medial part of $\mathrm{m}$. transversospinalis with a trellis-like arrangement of tendons suggests a significant stiffening and stabilizing effect of this muscle for the vertebral column. Among the thoracic epaxial muscle mass associated with the transverse processes, the medial part of $\mathrm{m}$. transversospinalis is reconstructed to have the largest cross-section, the highest tendon insertion angles and by its muscle fibers a direct connection to the neural spines. In sauropods with high neural spines, such as diplodocids and dicraeosaurids, the lever arm of the medial part of $\mathrm{m}$. transversospinalis to the center of rotation (the intervertebral articulation) would increase. This would increase the mechanical advantage of this muscle and its role in the stabilization of the vertebral column (see also Alexander, 1985; Wedel et al., 2000). Therefore, the medial part of m. transversospinalis might have probably contributed the most to a direct stabilization of the vertebral column. This stabilization was probably supplemented by the lateral part of $\mathrm{m}$. transversospinalis and by $\mathrm{m}$. longissimus dorsi, which were organized in tendon- and fascicle systems to brace the transverse processes against the neural spines.

M. iliocostalis did not directly act on the vertebral column and was positioned mostly ventrally to the vertebral column and vertically along the body wall. Its large size and assumed fascicular organization would have effectively stabilized the lateral sides of the trunk during simultaneous contraction. During unilateral contraction, $\mathrm{m}$. iliocostalis would have acted as moderate lateral flexor of the vertebral column, however, lateral flexibility was in most sauropods strongly restricted by the hyposphenal articulations and the epaxial musculature was acting mostly as stabilizing, but much less as flexing agent. As far as it can be judged from these reconstructions, the low flexibility of the dorsal vertebral column of most sauropods in combination with the reconstructed epaxial musculature would indicate slow asymmetric and symmetric locomotor styles.

The possible enlargement of $\mathrm{m}$. longissimus dorsi and $\mathrm{m}$. iliocostalis in Saltasauridae occurs in combination with a reduction of the hyposphene-hypantrum articulations and a retention of opisthocoelous vertebrae in the caudal trunk region, like in other macronarians. Reduction of these articulations would have allowed stronger lateral flexibility of the caudal trunk region than in other sauropods. The strong dorsal extension of $\mathrm{m}$. iliocostalis would have increased its ability to act as an efficient lateral flexor of the vertebral column. Together with the legs reconstructed in a "wide-gauge posture" (Wilson and Carrano, 1999), the modifications of the thoracic epaxial musculature in Saltasauridae therefore indicate differences in locomotor capabilities to other sauropods, such as increased trunk mobility or larger stride lengths.

\section{CONCLUSIONS AND PERSPECTIVE}

Their well-known dorsal osteology renders Diplodocidae and Dicraeosauridae an excellent group for the reconstruction of thoracic epaxial muscles in sauropods. The Extant Phylogenetic Bracket approach allows identification of unambiguous osteological correlates for the presence of the thoracic epaxial muscles $\mathrm{m}$. transversospinalis, $\mathrm{m}$. longissimus dorsi, and $\mathrm{m}$. iliocostalis in Diplodocidae and Dicraeosauridae, as well as in other eusauropods. Comparisons between the dorsal vertebrae of Diplodoci- 
dae, Dicraeosauridae, and other eusauropods show morphological differences that are indicative for differences in the configuration of the thoracic epaxial muscles. More detailed studies of this variation in different eusauropods is needed to explain aspects of the varying morphology of eusauropod dorsal vertebrae in relation to the configuration of the epaxial thoracic muscles. Hopefully, such future studies will also give hints to the evolutionary development of the different vertebral morphologies and to character polarities concerning character coding of vertebral morphologies.

The internal configuration of the epaxial muscles can only be reconstructed for the medial part of $\mathrm{m}$. transversospinalis on the basis of osteological correlates, whereas the strong segmentation of the other epaxial muscles is less well supported. Strongly segmented epaxial thoracic muscles, such as $\mathrm{m}$. transversospinalis and $\mathrm{m}$. longissimus dorsi, require only small insertional areas on the neural spines and transverse processes for their segments or tendon units, and therefore provide space for pneumatic diverticula. These pneumatic diverticula of eusauropods contribute much to weight reduction and facilitated size increase in certain clades.

The thoracic epaxial musculature plays an important role in trunk support. Variation in the size and tendon arrangement of the thoracic epaxial muscles in different eusauropods is directly connected with other, bony support structures, and indicates variation in the stabilization of the dorsal vertebral column. Such differences in trunk support and locomotion, along with differences in skull and tooth morphology, neck posture, and neck flexibility, give hints to ecological diversity of eusauropods. Studying trunk musculature of eusauropods is therefore only one part of an integrative approach, which should compare biological/ecological, mechanical, biogeographical and ichnological data for a better understanding of the evolution and ecology of eusauropods.

\section{ACKNOWLEDGMENTS}

I thank the following individuals for providing access to museum collections: B. Herkner (Senckenbergmuseum Frankfurt a.M.), W.-D. Heinrich and D. Unwin (Museum für Naturkunde der HU Berlin), W. Joyce and D. Brinkman (Yale Peabody Museum, New Haven), C. Mehling and I. Rutzky (American Museum of Natural History, New York), A. Henrici and D. Berman (Carnegie Museum for Natural History, Pittsburgh), M. Brett-Surman (Smithsonian Institution, Washington D.C.), J. F. Bonaparte and A. Kramarz (Museo Argentino de Ciencias Naturales, Buenos Aires), X. Xu and L. Liu (Institute of Vertebrate Paleontology and Paleoanthropology, Beijing), K. Li (Chengdu University of Technology, Chengdu) and K., Y., and M. Siber (Sauriermuseum Aathal). For their help and discussion while this paper was written, I am indebted to E. Frey (SMNK) and C. A. Meyer (NMB). A first draft benefited from the helpful comments and corrections of O. Wings and D. Fowler. I am especially grateful to J. A.Wilson and an anonymous reviewer for their helpful considerations and suggestions for improving a previous version of this paper. Three anonymous reviewers, whose corrections and suggestions proved again to be incredibly helpful, are thanked cordially. Finally, J. A.Wilson is thanked for his continuous dealing with this work and patient handling of the review processes. This study was financially supported by the Swiss National Science Foundation (SNF No. 200021-101494/1 and 200020-109131/1).

\section{LITERATURE CITED}

Alexander, R. M. 1985. Mechanics of posture and gait of some large dinosaurs. Zoological Journal of the Linnean Society of London $83: 1-25$.
Baumel, J. J., and L. M. Witmer. 1993. Osteologia; pp. 45-132 in J. J. Baumel, A. S. King, J. E. Breazile, H. E. Evans, and J. C. Vanden Berge (eds.), Handbook of Avian Anatomy: Nomina Anatomica Avium. Nuttal Ornithological Club, Cambridge, Massachusetts.

Baumel, J. J., A. S. King, J. E. Breazile, H. E. Evans, and J. VandenBerge. 1993. Handbook of Avian anatomy: Nomina Anatomica Avium. 2nd Edition, Volume 23. Nuttal Ornithological Society, Cambridge, Massachusetts, $779 \mathrm{pp}$.

Bellairs, A. d. A., and C. A. Jenkins. 1960. The skeleton of birds; pp. 241-300 in A. J. Marshall, (ed.), Biology and Comparative Physiology of Birds. Academic Press, New York.

Bonnan, M. F. 2003. The evolution of manus shape in sauropod dinosaurs: implications for functional morphology, forelimb orientation, and phylogeny. Journal of Vertebrate Paleontology 23:595-613.

Bonnan, M. F. 2005. Pes anatomy in sauropod dinosaurs: implications for functional morphology, evolution, and phylogeny; pp. 346-380 in V. Tidwell and K. Carpenter (eds.), Thunder-lizards. The Sauropodomorph Dinosaurs. Indiana University Press, Bloomington.

Bornhauser, C., and V. Ziswiler. 1983. Lokomotionsstudie und Funktionsanalyse der epaxonischen Muskulatur beim Nilkrokodil Crocodylus niloticus (Reptilia, Crocodylia). Revue suisse de Zoologie 90: 789-798.

Borsuk-Bialynicka, M. 1977. A new camarasaurid sauropod Opisthocoelicaudia skarzynskii, gen. et sp. n. from the Upper Cretaceous of Mongolia. Palaeontologica Polonica 37:5-64.

Bryant, H. N., and A. P. Russell. 1992. The role of phylogenetic analysis in the inference of unpreserved attributes of extinct taxa. Philosophical Transactions of the Royal Society of London B 337: 405-418.

Carrano, M. T. 2005. The evolution of sauropod locomotion; pp. 229-249 in K. A. Curry Rogers and J. A. Wilson (eds.), The Sauropods: Evolution and Paleobiology. University of California Press, Berkeley.

Carrano, M. T., and J. R. Hutchinson. 2002. Pelvic and hindlimb musculature of Tyrannosaurus rex (Dinosauria: Theropoda). Journal of Morphology 253:207-228.

Christiansen, P. 1997. Locomotion in sauropod dinosaurs. Gaia 14:45-75.

Coombs, W. P. Jr. 1975. Sauropod habits and habitats. Palaeogeography Palaeoclimatology Palaeoecology 17:1-33.

Coombs, W. P. Jr. 1978. Theoretical aspects of cursorial adaptations in dinosaurs. The Quarterly Review of Biology 53:393-418.

Curry Rogers, K. A. 2005. Titanosauria; pp. 50-103 in K. A. Curry Rogers and J. A. Wilson (eds.), The Sauropods: Evolution and Paleobiology. University of California Press, Berkeley.

Dong, Z., S. Zhou, and Y. Zhang. 1983. The dinosaurian remains from Sichuan Bain, China. Palaeontologia Sinica C 23:139-145.

Duncker, H.-R. 1971. The lung air sac system of birds. Advances in Anatomy, Embryology, and Cell Biology 45:1-171.

Emelianov, S. W. 1936. Die Morphologie der Tetrapodenrippen. Zoologische Jahrbücher, Abteilung für Anatomie und Ontogenie der Tiere 62:173-274.

Fisher, H. I., and D. C. Goodman. 1955. The myology of the Whooping Crane, Grus americana. Illinois Biological Monographs 24:1-127.

Frey, E. 1988a. Anatomie des Körperstammes von Alligator mississippiensis Daudin. Stuttgarter Beiträge zur Naturkunde A 24:1-106.

Frey, E. 1988b. Das Tragsystem der Krokodile - eine biomechanische und phylogenetische Analyse. Stuttgarter Beiträge zur Naturkunde, A 26:1-60.

Gasc, J.-P. 1981. Axial musculature; pp. $354-435$ in C. Gans and T. S. Parsons (eds.), Biology of the Reptilia. Academic Press, New York.

Gauthier, J. A. 1986. Saurischian monophyly and the origin of birds; pp. 1-55 in K. Padian, (ed.), The Origin of Birds and the Evolution of Flight. California Academy of Sciences, Memoir 8.

Gauthier, J. A., A. G. Kluge, and T. Rowe. 1988. Amniote phylogeny and the importance of fossils. Cladistics 4:105-209.

George, J. C., and A. J. Berger. 1966. Avian Myology. Academic Press, New York and London, 500 pp.

Gilmore, C. W. 1925. A nearly complete articulated skeleton of Camarasaurus, a saurischian dinosaur from the Dinosaur National Monument. Memoirs of the Carnegie Museum 10:347-384.

Gilmore, C. W. 1936. Osteology of Apatosaurus with special reference to specimens in the Carnegie Museum. Memoirs of the Carnegie Museum 11:175-300.

Hair, P. 1868. On the arrangement of the muscular fibers of the alligator. Journal of Anatomy 2:26-41. 
Harris, J. D. 2006. The significance of Suuwassea emilieae (Dinosauria: Sauropoda) for flagellicaudatan interrelationships and evolution. Journal of Systematic Palaeontology 4:185-198.

Harris, J. D., and P. Dodson. 2004. A new diplodocoid sauropod dinosaur from the Upper Jurassic Morrison Formation of Montana, USA. Acta Palaeontologica Polonica 49:197-210.

Hatcher, J. B. 1901. Diplodocus (Marsh): its osteolology, taxonomy, and probable habits, with a restoration of the skeleton. Memoirs of the Carnegie Museum 1:1-63.

Hatcher, J. B. 1903. Osteology of Haplocanthosaurus, with description of new species and remarks on probable habits of the Sauropoda, and the age and origin of the Atlantosaurus beds. Memoirs of the Carnegie Museum 2:1-72.

Henderson, D. M. 2004. Axial stress as a growth constraint in the vertebrae of sauropod dinosaurs. Journal of Morphology 260:297.

Henderson, D. M. 2006. Burly gaits: centers of mass, stability, and the trackways of sauropod dinosaurs. Journal of Vertebrate Paleontology 26:907-921.

Hoffstetter, R., and J.-P. Gasc. 1969. Vertebrae and ribs of modern reptiles; pp. 201-310 in C. Gans, A. d. A. Bellairs, and T. S. Parsons (eds.), Biology of the Reptilia. Academic Press.

Ikejiri, T., V. Tidwell, and D. L. Trexller. 2005. New adult specimens of Camarasaurus lentus highlight ontogenetic variation within the species; pp. 154-179 in V. Tidwell and K. Carpenter (eds.), Thunderlizards. The Sauropodomorph Dinosaurs. Indiana University Press, Bloomington.

Janensch, W. 1929. Die Wirbelsäule der Gattung Dicraeosaurus. Palaeontographica Supplement 7:37-133.

Janensch, W. 1961. Die Gliedmaszen und Gliedmaszengürtel der Sauropoden der Tendaguru-Schichten. Palaeontographica Supplement 7:177-235.

Kardong, K. V. 1998. Vertebrates. Comparative Anatomy, Function, Evolution. McGraw-Hill, Boston, 747 pp.

Kummer, B. 1959. Bauprinzipien des Säugerskeletts. Georg-ThiemeVerlag, Stuttgart, 235 pp.

Landolt, R., and G. Zweers. 1985. Anatomy of the muscle-bone apparatus of the cervical system in the mallard (Anas platyrhynchos L.). Netherlands Journal of Zoology 35:611-670.

Lehman, T. M., and A. B. Coulson. 2002. A juvenile specimen of the sauropod dinosaur Alamosaurus sanjuanensis from the Upper Cretaceous of Big Bend National Park, Texas. Journal of Paleontology 76:156-172.

Lull, R. S. 1919. The sauropod dinosaur Barosaurus Marsh. Memoirs of the Conneticut Academy of Arts and Sciences 6:1-42.

McIntosh, J. S. 1981. Annotated catalogue of the dinosaurs (Reptilia: Archosauria) in the collections of the Carnegie Museum of Natural History. Bulletin of the Carnegie Museum of Natural History 18:1-67.

McIntosh, J. S. 2005. The Genus Barosaurus Marsh (Sauropoda, Diplodocidae); pp. 38-77 in V. Tidwell and K. Carpenter (eds.), Thunderlizards. The Sauropodomorph Dinosaurs. Indiana University Press, Bloomington.

McIntosh, J. S., and M. E. Williams. 1988. A new species of sauropod dinosaur, Haplocanthosaurus delfsi, sp. nov., from the Upper Jurassic Morrison Fm. of Colorado. Kirtlandia 43:3-26.

McIntosh, J. S., W. E. Miller, K. L. Stadtman, and D. D. Gillette. 1996a. The osteology of Camarasaurus lewisi (Jensen, 1988). Brigham Young University Geology Studies 41:73-115.

McIntosh, J. S., W. E. Miles, K. C. Cloward, and J. R. Parker. 1996b. A new nearly complete skeleton of Camarasaurus. Bulletin of the Gunma Museum of Natural History 17:1-87.

Molnar, R. E., and E. Frey. 1987. The paravertebral elements of the Australian ankylosaur Minmi (Reptilia: Ornithischia, Cretaceous). Neues Jahrbuch für Geologie und Mineralogie, Abhandlungen 75:19-37.

Mook, C. C. 1914. The dorsal vertebrae of Camarasaurus Cope. Bulletin of the American Museum of Natural History 33:223-227.

Murakami, G., K. Akita, and T. Sato. 1991. Arrangement and innervation of the iliocostalis and longissimus muscles of the brown caiman (Caiman crocodilus fuscus: Alligatoridae, Crocodilia). American Journal of Anatomy 192:241-256.

Norman, D. B. 1980. On the ornithischian dinosaur Iguanodon bernissartensis from the Lower Cretaceous of Bernissart (Belgium). Mémoires de l'Institut Royal des Sciences Naturelles de Belgique 178:1-103.
Norman, D. B. 1986. On the anatomy of Iguanodon atherfieldensis (Ornithischia: Ornithopoda). Bulletin de l'Institut Royal des Sciences Naturelles de Belgique, Sciences de la Terre 56:281-372.

O'Connor, P. M. 2004. Pulmonary pneumaticity in the postcranial skeleton of extant aves: a case study examining Anseriformes. Journal of Morphology 261:141-161.

Organ, C. L. 2006. Thoracic epaxial muscles in living archosaurs and ornithopod dinosaurs. Anatomical Record 288A:782-793.

Osborn, H. F., and C. C. Mook. 1921. Camarasaurus, Amphicoelias, and other sauropods of Cope. Memoirs of the American Museum of Natural History 3:247-387.

Peng, G., Y. Ye, Y. Gao, C. Shu, and S. Jiang. 2005. Jurassic dinosaur faunas in Zigong. Zigong Dinosaur Museum, Zigong, 236 pp.

Powell, J. E. 1992. Osteología de Saltasaurus loricatus (SauropodaTitanosauridae) del Cretácico superior del Noroeste Argentino; pp. 165-230 in J. L. Sanz and A. D. Buscalioni (eds.), Los Dinosaurios y su Entorno biótico. Instituto "Juan de Valdéz", Cuenca, Spain.

Powell, J. E. 2003. Revision of South American titanosaurid dinosaurs: palaeobiological, palaeobiogeographical and phylogenetic aspects. Records of the Queen Victoria Museum 111:1-173.

Rauhut, O. W. M., K. Remes, R. Fechner, G. Cladera, and P. Puerta. 2005. Discovery of a short-necked sauropod dinosaur from the Late Jurassic period of Patagonia. Nature 435:670-672.

Rothschild, B. M., and R. E. Molnar. 2005. Sauropod stress fractures as clues to activity; pp. 381-392 in V. Tidwell and K. Carpenter (eds.), Thunder-lizards. The Sauropodomorph Dinosaurs. Indiana University Press, Bloomington.

Salgado, L. 1999. The macroevolution of the Diplodocimorpha (Dinosauria; Sauropoda): a developmental model. Ameghiniana 36: 203-216.

Salgado, L., and J. F. Bonaparte. 1991. Un nuevo saurópodo Dicraeosauridae, Amargasaurus cazaui gen. et sp. nov. de la Formación La Amarga, Neocomiano de la Provincia Neuquén, Argentina. Ameghiniana 28:222-236.

Salisbury, S. W. 2001. A biomechanical transformation model for the evolution of the eusuchian-type bracing system. PhD thesis Biological Sciences. University of New South Wales, Sydney, 554 pp.

Salisbury, S. W., and E. Frey. 2001. A biomechanical transformation model for the evolution of semi-spheroidal articulations between adjoining vertebral bodies in crocodilians; pp. $85-134$ in G. C. Grigg, F. Seebacher, and C. E. Franklin (eds.), Crocodilian Biology and Evolution. Surry Beatty \& Sons, Chipping Norton, Australia.

Schwarz, D., E. Frey, and C. A. Meyer. 2007. Pneumaticity and softtissue reconstructions in the neck of diplodocid and dicraeosaurid sauropods. Acta Palaeontologica Polonica 52:167-188.

Seidel, M. R. 1979. The osteoderms of the American Alligator and their functional significance. Herpetologica 35:375-380.

Sereno, P. C. 1999. The evolution of dinosaurs. Science 284:2137-2147.

Slijper, E. J. 1946. Comparative biologic-anatomical investigation on the vertebral column and spinal musculature of mammals. Verhandelingen Der Koninklijke Ned. Akademie Van Wetenschappen, Afdeeling Natuurkunde, Tweede Sectie 42:1-128.

Tsuihiji, T. 2005. Homologies of the transversospinalis muscles in the anterior presacral region of Sauria (Crown Diapsida). Journal of Morphology 263:151-178.

Upchurch, P., P. M. Barrett, and P. Dodson. 2004a. Sauropoda; pp. 259-322 in D. B. Weishampel, P. Dodson, and H. Osmólska (eds.), The Dinosauria. (2nd ed.). University of California Press, Berkeley.

Upchurch, P., Y. Tomida, and P. M. Barrett. 2004b. A new specimen of Apatosaurus ajax (Sauropoda: Diplodocidae) from the Morrison Formation (Upper Jurassic) of Wyoming, USA. National Science Museum Monographs 26:1-107.

Vallois, H. V. 1922. Les transformations de la musculature de l'épisome chez les vertébrés. Archives de Morphologie Generale et Experimentale 13:1-538.

Wedel, M. J. 2003. The evolution of vertebral pneumaticity in sauropod dinosaurs. Journal of Vertebrate Paleontology 23:344-357.

Wedel, M. J., R. I. Cifelli, and R. K. Sanders. 2000. Osteology, paleobiology, and relationships of the sauropod dinosaur Sauroposeidon. Acta Palaeontologica Polonica 45:343-388.

Wettstein, O. v. 1937. Crocodilia; pp. 236-424 in W. Kükenthal (ed.), Handbuch der Zoologie. Fischer-Verlag, Jena.

Wilson, J. A. 1999. A nomenclature for vertebral laminae in sauropods and other saurischian dinosaurs. Journal of Vertebrate Paleontology 19:639-653. 
Wilson, J. A. 2002. Sauropod dinosaur phylogeny: critique and cladistic analysis. Zoological Journal of the Linnean Society 136:217-276.

Wilson, J. A. 2005. Overview of sauropod phylogeny and evolution; pp. 15-49 in K. A. Curry Rogers and J. A. Wilson (eds.), The Sauropods: Evolution and Paleobiology. University of California Press, Berkeley.

Wilson, J. A., and P. C. Sereno. 1998. Early evolution and higher-level phylogeny of sauropod dinosaurs. Journal of Vertebrate Paleontology, Memoir 5 18:1-68.

Wilson, J. A., and M. T. Carrano. 1999. Titanosaurs and the origin of "wide-gauge" trackways: a biomechanical and systematic perspective on sauropod locomotion. Paleobiology 25:252-267.

Witmer, L. M. 1995. The Extant Phylogenetic Bracket and the importance of reconstructing soft tissues in fossils; pp. 19-33 in J. J. Thomason (ed.), Functional Morphology in Vertebrate Paleontology. Cambridge University Press, Cambridge.
Witmer, L. M. 1997. The evolution of the antorbital cavity in archosaurs: a study in soft-tissue reconstruction in the fossil record with analysis of the function of pneumaticity. Journal of Vertebrate Paleontology, Memoir 3 17:1-73.

Wood, J. 2006. A study of Camarasaurus' (Dinosauria: Sauropoda) torso and its biomechanical implications. M.S. thesis Department of Earth and Environmental Sciences, University of New Orleans, New Orleans, $141 \mathrm{pp}$.

Zhang, Y., D. Yang, and G. Peng. 1984. New materials of Shunosaurus from the Middle Jurassic Dashanpu, Zigong, Sichuan. Journal of the Chengdu College of Geology Suppl. 2:1-12.

Zusi, R. L., and G. D. Bentz. 1984. Myology of the purple-throated carib (Eulampis jugularis) and other hummingbirds (Aves: Trochilidae) Smithsonian Contributions to Zoology 385:1-70.

Submitted July 29, 2007; accepted October 20, 2008. 